\title{
YÖK Dersleri Platformundaki Muhasebe Kitaplarının Bibliyometrik Analizle İncelenmesi (Araştırma Makalesi)
}

\section{Analysis of Accounting Books on YÖK Courses Platform with Bibliometric Analysis}

Doi: 10.29023/alanyaakademik.992169

\section{Kürşad ÇAVUŞOĞLU}

Ögrr.Gör.Dr., Mersin Üniversitesi, Anamur MYO, İsletme Yönetimi,

kursatcavusoglu@mersin.edu.tr

Orcid No: 0000-0002-6820-3790

Bu makaleye atıfta bulunmak için: Çavuşoğlu, K. (2022). "YÖK Dersleri Platformundaki Muhasebe Kitaplarının Bibliyometrik Analizle İncelenmesi”, Alanya Akademik Bakış, 6(1), Sayfa No. 1673-1701.

\begin{abstract}
ÖZET
Anahtar kelimeler: Muhasebe kitabı, YÖK dersleri platformu, bibliyometrik analiz

Makale Geliş Tarihi: 07.09.2021

Kabul Tarihi:

29.12.2021

Uzaktan eğitimin önemi COVID-19 pandemisinden sonra artmıştır. Türkiye'de YÖK dersleri platformu, yükseköğretim düzeyinde uzaktan eğitim ders içerikleri sunan bir platformdur. Bu çalışmanın amacı YÖK dersleri platformundaki 41 muhasebe kitabinin sayfa saylsi, unvan, kaynak dili, kaynak türü, kaynak yılı gibi birtakım özellikler açısından bibliyometrik analizle incelenmesidir. Editörlerin ă̆ırlıkl kısmının 'Profesör Doktor' unvanlı olduğu, tüm muhasebe kategorilerinde 'Profesör Doktor' unvanl bölüm yazarı sayısının diğer unvanlardan daha fazla olduğu, muhasebe bilgi sistemi/teknolojisi kategorisi hariç diğer tüm kategorilerde Türkçe kaynakların ă̆ırlığının yabancı dildeki kaynaklara göre daha fazla olduğu görülmüşürr. Tüm muhasebe kitaplarında yararlanılan kaynakların tamamı en çok başvurulandan en az başvurulana doğru sıralandığında, birinci sırada kitap, ikinci sırada dergi, üçüncü strada internet, dördüncü sirada mevzuat, beşinci sırada tez, altıncı sirada diğer kaynaklar ve son strada bildirinin yer aldı ̆̆ $ı$ belirlenmistir.
\end{abstract}

Keywords:

Accounting book,

YÖK courses

platform,

Bibliometric

analysis

\section{ABSTRACT}

The importance of distance education has increased after the COVID-19 pandemic. In Turkey, the YÖK courses platform is a platform that offers distance education course content at the higher education level. The aim of this study is to examine 41 accounting books in the YÖK courses platform with bibliometric analysis in terms of some features such as page number, title, reference language, reference type, reference year. It was observed that the majority of the editors were titled as 'Professor Doctor', the number of chapter writers with the title of 'Professor Doctor' was higher in all accounting categories than other titles and the weight of Turkish references was higher than the references in foreign languages in all other categories except the accounting information system/technology category. When all the references used in all accounting books were ranked from the most frequently used to the least referenced, it was determined that the book was the first, the journal was the second, the internet was the third, the legislation was the 


\section{GÍRİŞ}

COVID-19, ilk kez aralık ayının sonlarında solunum yolu semptomları gösteren bir grup hastada gerçekleş̧tirilen araştırmalar neticesinde 13 Ocak 2020 tarihinde tanımlanmış bir hastalıktır. Dünya Sağlık Örgütü, COVID-19 için 11 Mart 2020 tarihinde pandemi ilan etmiştir (T.C. Sağlık Bakanlığı COVID-19 Bilgilendirme Platformu, 2021).

Pandemi ticaretten ekonomiye, sağlıktan ulaşıma pek çok alanı ve sektörü etkilemiştir. Etkilediği bu alanlardan birisi de eğitim olmuştur. Pandeminin ilanıyla birlikte daha önceleri tamamlayıcı veya alternatif bir eğitim türü olarak görülen uzaktan eğitim de zorunluluk olmuştur.

Uzaktan eğitim kavramı ilk kez Wisconsin Üniversitesi'nin 1892 yılına ait kataloğunda yer alan bir kavram olup, Wisconsin Üniversitesi'nin yöneticisi William Lighty 1906 yllında yazılan bir yazı da bu kavramı ilk defa kullanmıştır (Kaya, 2002: 9). Uzaktan eğitim bilgi, iletişim, öğretim teknolojilerine ait ortamların, araç-gereçlerin, materyallerin, uygulamaların kullanılarak zamana ve yere bağlı olmadan birbirinden uzaktan bulunan öğrencilerin öğretmenle, diğer öğrencilerle, içerikle, materyallerle karşılıklı etkileşime girdiği bir eğitim-öğretim sistemi olarak tanımlanabilir (Aydemir, 2018: 14). İlk aşamasında yazarak gerçekleştirilen uzaktan eğitim uygulamalarında zaman geçtikçe radyo, televizyon, telefon, bilgisayar gibi araçlardan da yararlanılmış olup çağımızda ise e-posta, bilgisayar üzerinden konferans, internet benzeri mültimedya sunu sistemleri kullanılmaktadır (Kaya, 2002: 11).

Uzaktan eğitimden etkili şekilde faydalanabilmek için uzaktan eğitim alanlara ilişkin etkili öğretim stratejilerinin oluşturulmasına ve uygulanmasına, uzaktan eğitim derslerinin titiz bir şekilde dizayn edilmesine, öğrencilerin sunulacak destek hizmetlerden yeteri kadar yararlanmasına, öğrenci-öğretmen ve öğrenci-öğrenci arasında etkileşimin kurulmasına, öğrencilerin uzaktan eğitim faaliyeti sonuncunda ne elde edecekleri konusunda bilgilendirilmelerine, ölçme-değerlendirme faaliyetlerine, öğrenme çıtıllarına ve öğrenme deneyimlerine önem verilmelidir (Aydemir, 2018: 14).

Pandeminin ne zaman sona ereceği ve etkilerinin ne kadar devam edeceği tam olarak bilinmemektedir. Ayrıca pandemi sona erse ve etkileri tümüyle ortadan kalksa bile uzaktan eğitimin eğitim sistemi içerisindeki yerinin pandemi öncesine göre daha fazla önem taşıyacağ 1 beklenebilir.

\section{LITERATÜR TARAMASI}

Hassan vd. (2021), Scopus veritabanından 2010 ile 2020 yılları arasında 'Journal of Islamic Accounting and Business Research' dergisine ait 287 yayımlanmış makaleyi ve eleştiri yazısını bibliyometrik yaklaşımla araştırdıkları çalışmalarında, derginin incelenen dönem içerisinde üretkenliğinin ve etkisinin önemli derecede arttığını, alanındaki baskın dergilerden biri olduğunu, yazarların bağlı oldukları ülke açısından ilk sırada Malezya'nın, ikinci sırada Birleşik Krallık'ın yer aldığını, yazarların bağlı olduğu kurum açısından ilk üç sırada sırasıyla 'International Islamic University Malaysia', 'Universiti Utara Malaysia' ve 'Universiti Kebangsaan Malaysia' bulunduğunu belirtmişlerdir. 
Kumar vd. (2020), 'International Journal of Accounting Information Systems' dergisinde 2000 ile 2019 yılları arasında yayımlanmış makaleleri bibliyometrik analizle inceledikleri çalışmalarında hem yayım sayısında hem de atıf sayısında istikrarlı bir artış olduğunu, dergiye katkı sağlayanlar arasında Amerika Birleşik Devletleri kurumlarına bağlı çalışan yazarların ağırlıkta olduğunu, muhasebede bilgi teknolojisi ve yeni teknolojiler, teknolojinin güvence ve kurumsal açıklamalara uygulanması konularının dergide yıllar boyunca işlenen en baskın konular olduğunu ifade etmişlerdir.

Akpınar ve Yıldız (2020: 97), içerik ve yazar yönünden profilini belirlemek, seneler içerisinde hangi konuların daha fazla önem kazandığını tespit etmek amacıyla 510 adet Türkçe yazılmış muhasebe kitabını incelemişlerdir. İncelemeleri sonucunda bilgisayarlı muhasebe, muhasebe denetimi, yönetim ve maliyet muhasebesi, dış ticaret işlemleri muhasebesi, banka muhasebesi, finansman yöntemleri ve türev araçlara yönelik muhasebe işlemleri ile ilgili konuların hala güncel olduklarını, enflasyon muhasebesi, muhasebe ve finansal raporlama standartları, entegre raporlama ile ilgili konuların ise daha fazla ön planda yer aldıklarını, ayrıca kitapların en fazla Gazi Kitapevi tarafından yayınladığını ve yazarların çoğunlukla akademisyen olduklarını tespit etmişlerdir.

Koç ve Yüncü (2020), İstanbul Üniversitesi Sosyal Bilimler Enstitüsü Muhasebe Bilim Dalında 2004 ile 2018 yılları arasında tamamlanmış 106 lisansüstü tezle ilgili yaptıkları bibliyometrik analiz çalışmalarında, unvan bakımında profesör doktor unvanlıların daha fazla lisansüstü tez danışmanlığı yaptığını, ortalama sayfa sayısı açısından yüksek lisans tezlerinin 156 sayfa, doktora tezlerinin ise 256 sayfa olduğunu, lisansüstü tezlerde çoğunlukla araştırılmış ortak konuların finansal muhasebe, denetim, maliyet muhasebesi, vergi ve finansal kurumlar muhasebesi olduğunu ifade etmişlerdir.

Akyüz ve Yeşil (2019: 101), 12 ulusal ve 7 uluslararası yönetim muhasebesi kitabını inceledikleri çalışmalarında kitapların birbirlerinden farklı ve benzer yönlerini belirlemeye çalışmış olup, yönetim muhasebesi alanındaki yeni kitaplarda olması gereken çeşitli alternatif konu başlıkları önermişlerdir.

Doğan ve Ertugay (2019: 865), 10 tane lisans genel muhasebe ders kitabının okunabilirlik puanlarını hesaplayarak hedef okuyucu kitlesine uygunluğu araştırdıkları çalışmalarında, inceledikleri kitapların büyük kısmının, lisans seviyesindeki hedef okuyucu kitlesi için okunabilirliklerinin uygun olduğunu belirtmişlerdir.

Özbek ve Badem (2018: 216), 2008 ile 2017 yılları arasında Muhasebe ve Vergi Uygulamaları Dergisi'nde yayımlanan 149 makaleyi bibliyometrik analize tabi tutmuşlardır. Analizleri sonucunda cinsiyet açısından erkek yazarların daha fazla yayın yaptıkları, unvan açısından yardımcı doçent doktor unvanlı yazarların en fazla yayın yaptıklarını, makale başına ortalama sayfa sayısının 21,58 sayfa olduğunu, makale başına ortalama kaynak sayısının yaklaşık 22 olduğunu, yerli kaynaklardan daha fazla yararlanıldığını, en fazla işlenilen konunun muhasebe standartları olduğunu belirtmişlerdir.

Gündüz’ün (2018: 236), 2014 ile 2016 yılları arasında akademik dergilerde yer alan muhasebeyle ilgili 635 makaleyi bibliyometrik analizle incelediği çalışmasında, makalelerin vakıf, dernek ve diğer kuruluşlara ait dergilerde daha fazla yayınlandığı, en fazla yayının Muhasebe ve Denetim Standartları, Muhasebe Denetimi ve Finansal Muhasebe kategorilerinde görüldüğü sonucuna ulaşmıştır. 
Yeşil ve Akyüz (2018), 25.05.2018 tarihi itibariyle saptanan 320 doktora tezini bibliyometrik analizle inceledikleri çalışmalarında, unvan bakımından en fazla profesör doktor unvanlı akademisyenlerin tez danışmanlığı yaptığını, kaydolduğu üniversite açısından Marmara Üniversitesi'ne kayıtlı öğrencilerin daha fazla doktora tezi çalışması yaptıklarını, en çok işlenen tez konusun ise Türkiye Muhasebe Standartları (TMS) / Türkiye Finansal Raporlama Standartları (TFRS) olduğunu belirtmişlerdir.

Merigó ve Yang (2017), 'Web of Science' veri tabanını kullanarak muhasebe araştırmalarına ilişkin bibliyometrik genel bakış sundukları çalışmalarında en etkili dergilerin 'The Journal of Accounting and Economics', 'Journal of Accounting Research', 'The Accounting Review' ve 'Accounting, Organizations and Society' dergileri olduğunu, Amerika Birleşik Devletleri kurumlarının dünya çapında en etkin kurumlar olduğunu ve diğer alanlara kıyasla muhasebe yayınlarının atıf düzeyinin çok düşük olduğu sonucuna ulaşmışlardır.

Kıymetli Şen vd. (2017), 2009 ile 2015 yılları arasında Muhasebe ve Bilim Dünyası Dergisi, Muhasebe ve Finansman Dergisi, Muhasebe ve Denetime Bakış Dergisi, Muhasebe ve Vergi Uygulamaları Dergisi'nde yayımlanan 852 makaleyi bibliyometrik analizle araştırdıkları çalışmalarında, unvan açısından yardımcı doçent doktor unvanlı yazarların daha fazla makale yayınladıkları, muhasebe yönünden en çok işlenilen konunun muhasebe standartları olduğu, atıf sayısı açısından en fazla atfın dergilere yapıldığı, sonra sırasıyla kitaplara, internet kaynaklarına, bildirilere, en az atfın ise lisansüstü tezlere yapıldığı neticesine varmışlardır.

Apak vd. (2016), Temmuz-2011 ile Ocak-2016 dönemleri arasında Muhasebe ve Finans Tarihi Araştırmaları Dergisi'nde yayımlanmış 107 makaleyi bibliyometrik analize tabi tuttukları çalışmalarında en fazla atfın dergilere yapıldığı, sonrasında sırasıyla kitaplara, diğer kaynaklara ve en az atfın ise bildirilere yapıldığını ifade etmişlerdir.

Hotamışlı ve Erem (2014: 1), 2005-2013 yılları arasında Muhasebe ve Finansman Dergisi'nde yayınlanmış 562 makaleyi bibliyometrik analizle inceledikleri çalışmalarında, konu yönünden finansal performans, kamu ekonomisi ve finansal piyasalar konularının ağırlık taşıdığını, atıf yönünden kaynakların birinci olarak dergiler, ikinci olarak diğer kaynaklar, üçüncü olarak kitaplar ve son olarak bildiriler şeklinde sıralandıklarını, unvan açısından yardımcı doçent doktor unvanlı yazarların daha fazla yayın yaptıklarını, makale başına ortalama sayfa sayısının 12,72 olduğunu, yabancı kaynaklardan daha fazla faydalanıldığını belirtmişlerdir.

Literatür incelendiğinde muhasebe kitaplarının özelliklerini inceleyen az çalışma mevcuttur. Muhasebe alanındaki bibliyometrik analizle ilgili çalışmaların daha çok akademik dergilerinde yayınlanan makaleler ile muhasebe alanındaki lisansüstü tezler ile ilgili olduğu görülmektedir. Bu çalışmada diğer çalışmalardan farklı olarak açık erişime sunulan muhasebe kitaplarına ait kaynakça verileri analiz edilerek, muhasebe kitaplarının kaynak sayısına, diline, türüne ve yayın yılına göre dağılımı gösterilmeye çalışılmıştır.

\section{ARAŞTIRMA METODOLOJISİ}

\subsection{Araştırmanın Amacı, Kapsamı ve Soruları}

Türkiye'de özellikle pandemi döneminde yükseköğretim düzeyindeki uzaktan eğitim sırasında yararlanılan dijital ders materyallerinden biri de YÖK (Yükseköğretim Kurulu) Dersleri Platformu olmuştur. Ders materyalleri verilen uzaktan eğitimin kalitesini de etkileyebilmektedir. Bu çalışmanın amacı YÖK Dersleri Platformu içerisinde çeşitli fakülte ve 
meslek yüksekokulu (MYO) düzeyinde açık erişime sunulan muhasebe kitaplarının sayfa sayısı, unvan, kaynak dili, kaynak türü, kaynak yılı gibi birtakım özellikler açısından bibliyometrik analizle incelenmesidir. Böylece sürekli gelişimi esas alan YÖK Dersleri Platformu (YÖK Dersleri Platformu, 2021) içerisindeki muhasebe kitaplarının niteliklerinin ortaya konulması ve gelecekte oluşturulacak muhasebeye ilişkin dijital ders materyalleri ile ilgili öneriler sunulması amaçlanmaktadır. Bu çerçevede aşağıdaki sorulara yanıt aranmaya çalışılmıştır:

- Muhasebe kitaplarının tümünün minimum, maksimum, ortalama sayfa sayısı kaçtır?

- Muhasebe kitaplarının tümünde editörlerin unvanlarına göre dağılımı nasıldır?

- Muhasebe kitaplarının tümünde yayınevine göre dağılım ne şekildedir?

- Muhasebe kitaplarının tümünde yıllara göre dağılım nasıldır?

- Muhasebe kitaplarının tümünün açı erişime sunulduğu fakülte/meslek yüksekokulu/lisans tamamlama düzeyine göre dağılımı ne şekildedir?

- $\quad$ Muhasebe kitaplarının tümünün bölüm sayısına göre dağılımı nasıldır?

- Muhasebe kategorisine göre muhasebe kitaplarındaki bölümlerin minimum, maksimum, ortalama sayfa sayısı kaçtır?

- Muhasebe kategorisine göre muhasebe kitaplarındaki bölüm yazarlarının unvana göre dağılımı nasıldır?

- Muhasebe kategorisine göre muhasebe kitaplarındaki bölümlerde yararlanılan kaynakların kaynak türüne göre dağılımı ne şekildedir?

- Muhasebe kategorisine göre muhasebe kitaplarındaki bölümlerde yararlanılan kaynakların kaynak diline göre dağılımı nasıldır?

- Muhasebe kategorisine göre muhasebe kitaplarındaki bölümlerde yararlanılan kaynakların kaynak yılına göre dağılımı nasıldır?

Çalışmada ikincil verilerden faydalanılmış olup, verilerin toplanması için YÖK Dersleri Platformunda dijital ders içerikleri incelenmiştir. YÖK Dersleri Platformu çeşitli üniversitelerin hazırladığı dijital ders içeriklerini açık erişime sunan bir ara yüzdür (YÖK Dersleri Platformu, 2021). YÖK Dersleri platformunda Edebiyat Fakültesi, Eğitim Fakültesi, Fen Fakültesi, İktisadi ve İdari Bilimler Fakültesi, İletişim Fakültesi, Mühendislik Fakültesi, Sağlık Bilimleri Fakültesi, Turizm Fakültesi, Adalet Meslek Yüksekokulu, Sağlık Hizmetleri Meslek Yüksekokulu, Sosyal Bilimler Meslek Yüksekokulu ve Teknik Bilimler Meslek Yüksekokulu düzeyinde ders içerikleri sunulmaktadır (YÖK Dersleri Platformu, 2021).

YÖK Dersleri Platformunda öncelikle isminde muhasebe kelimesi geçen kitaplar ile muhasebe kelimesi geçmese bile içerik yönünden muhasebeyle ilgili kitaplar, 18 Mayıs 2021 tarihi itibariyle tüm fakülte ve meslek yüksekokulu düzeyinde, ayrıca Lisans Tamamlama, Ortak Dersler Bölümü ve Dijital Eğitim Dersleri içerisinde taranmıştır. Kitap niteliği taşımayıp ders notu niteliğinde olduğu ve kaynakça verileri eksik olduğu için İstanbul Üniversitesi'ne ait yayınlar araştırmaya dâhil edilmemiştir. Ayrıca yabancı dilde yazılmış kitaplar da araştırma kapsamı dışında tutulmuştur. Bu çerçevede Anadolu Üniversitesi ile Atatürk Üniversitesi yayınlarına ait Türkçe yazılmış 41 adet muhasebeyle ilgili kitaba ulaşılmıştır. Araştırmada bu 41 adet kitap analize tabi tutulmuştur. 


\subsection{Araştırmanın Yöntemi}

41 adet muhasebe kitabından elde edilen verileri analiz etmek için bibliyometrik analizden yararlanılmıştır.

Bibliyometri terimi, kitapları ya da kaynak dizinini ifade eden bibliyo kelimesi ile ölçmeyi ifade eden metrik kelimelerinin birleşmesinden oluşmuştur (Norton, 2008: 63). Bibliyometri kitap, kitap bölümü, dergi makaleleri, bildiriler gibi klasik yayınların yanı sıra internetteki akademik yayınların özellikle ölçülmesine odaklanmaktadır (Ball, 2018: 15-16). Bibliyometrinin temel yöntemleri yayınlanan yayın sayısını belirleyerek başlar ve sonrasında bu yayınların topluluk içerisinde, yani örneğin diğer bireyler, yazarlar, akademisyen arasında, nasıl kavrandığını ve ne kadar kullanıldığını araştırır (Ball, 2018: 17). Bu çerçevede bibliyometri belirli kelimelerin, terimlerin, atıfların, yazarlıkların ve benzeri belirli özelliklerin ortaya çıkma sıklığını belirleme gibi çeşitli ölçümler yaparak bilgiyi araştırabilir ve belirli bir alandaki, atıflardaki, terim kullanımındaki ya da yayınlardaki yazarlıkla ilgili örüntüleri tespit etmek için de uygulanabilir. Ayrıca başlık kümelerini, dergi kümelerini, disiplin ve yayılma ağlarını tanımlamak için de kullanilabilir (Norton, 2008: 64).

\subsection{Araştırmanın Bulguları}

Muhasebe kitaplarının tümüne ilişkin genel bilgiler verildikten sonra muhasebe kategorilerine göre muhasebe kitaplarına ait bulgular sunulmuştur. Muhasebe kategorileri muhasebe türlerine ve kitapların içeriğine göre belirlenmiştir. Genel Muhasebe, Dönem Sonu Muhasebesi, Yönetim/Maliyet Muhasebesi, Muhasebe Denetimi, Muhasebe Bilgi Sistemi/Teknolojisi, Şirketler Muhasebesi, Dış Ticaret Işlemleri Muhasebesi, Banka/Sigorta Muhasebesi, Muhasebe Uygulamalarl, Inşaat Muhasebesi, Muhasebe ve Hukuk ile Mali Tablolar Analizi/Finansal Analiz olmak üzere 12 muhasebe kategorisi saptanmıştır.

\subsubsection{Muhasebe Kitaplarının Tümüne İlişkin Bulgular}

Kitap adına, kitabın muhasebe kategorisine, editörlerin unvanına, yayınevine, yayın yılına, sayfa sayısına (kapak, içindekiler dahil), bölüm sayısına ve kitabın açık erişime sunulduğu fakülte/meslek yüksek okuluna ait bilgiler verilmeye çalış1lmıştır.

Tablo 1. Araştırma Kapsamında YÖK Dersleri Platformunda Açık Erişime Sunulan Muhasebe Kitapları

\begin{tabular}{|c|c|c|c|c|c|c|c|c|}
\hline \multirow[b]{2}{*}{ Kitap Adı } & \multicolumn{3}{|c|}{$\begin{array}{c}\text { Editörlerin } \\
\text { Unvanı }\end{array}$} & \multirow[b]{2}{*}{ Yayınevi } & \multirow[b]{2}{*}{$\begin{array}{c}\text { Yayın } \\
\text { Yılı }\end{array}$} & \multirow[b]{2}{*}{$\begin{array}{l}\text { Sayfa } \\
\text { Sayısı }\end{array}$} & \multirow[b]{2}{*}{$\begin{array}{l}\text { Bölüm } \\
\text { Sayısı }\end{array}$} & \multirow{2}{*}{$\begin{array}{c}\text { Kitabın } \\
\text { Sunulduğu } \\
\text { Fakülte/Bölüm/ } \\
\text { Lisans } \\
\text { Tamamlama }\end{array}$} \\
\hline & 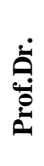 & $\stackrel{\dot{\Delta}}{\stackrel{\dot{0}}{\circ}}$ & 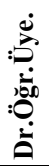 & & & & & \\
\hline $\begin{array}{c}\text { Dönem Sonu } \\
\text { Muhasebe İşlemleri }\end{array}$ & 1 & & & $\begin{array}{c}\text { Atatürk } \\
\text { Üniversitesi }\end{array}$ & 2017 & 317 & 14 & $\begin{array}{l}\text { İ̈BF / Sosyal } \\
\text { Bilimler MYO }\end{array}$ \\
\hline $\begin{array}{l}\text { Dönemsonu } \\
\text { İşlemleri }\end{array}$ & 1 & & & $\begin{array}{c}\text { Anadolu } \\
\text { Üniversitesi }\end{array}$ & 2020 & 267 & 8 & İIBF \\
\hline Genel Muhasebe & 1 & & & $\begin{array}{c}\text { Atatürk } \\
\text { Üniversitesi }\end{array}$ & 2011 & 344 & 14 & $\begin{array}{c}\text { İİBF / Sosyal } \\
\text { Bilimler MYO / } \\
\text { Sağlık Bilimleri } \\
\text { Fakültesi / Adalet } \\
\text { MYO / Sağlık } \\
\text { Hizmetleri MYO }\end{array}$ \\
\hline
\end{tabular}


ALANYA AKADEMIK BAKIŞ DERGİSİ 6/1 (2022)

\begin{tabular}{|c|c|c|c|c|c|c|c|c|}
\hline Genel Muhasebe I & 2 & & & $\begin{array}{l}\text { Anadolu } \\
\text { Üniversitesi }\end{array}$ & 2018 & 206 & 8 & $\begin{array}{c}\text { İIBF / Sosyal } \\
\text { Bilimler MYO / } \\
\text { Sağllk Bilimleri } \\
\text { Fakültesi / Turizm } \\
\text { Fakültesi / Lisans } \\
\text { Tamamlama } \\
\end{array}$ \\
\hline Genel Muhasebe II & 1 & & & $\begin{array}{l}\text { Anadolu } \\
\text { Üniversitesi }\end{array}$ & 2019 & 172 & 7 & $\begin{array}{c}\text { İIBF / Sosyal } \\
\text { Bilimler MYO / } \\
\text { Sağllk Bilimleri } \\
\text { Fakültesi / Turizm } \\
\text { Fakültesi / Lisans } \\
\text { Tamamlama } \\
\end{array}$ \\
\hline Maliyet Muhasebesi & 1 & 1 & & $\begin{array}{c}\text { Anadolu } \\
\text { Üniversitesi }\end{array}$ & 2018 & 294 & 8 & İİBF \\
\hline $\begin{array}{l}\text { Maliyet Muhasebesi } \\
\text { I }\end{array}$ & & & & $\begin{array}{c}\text { Atatürk } \\
\text { Üniversitesi }\end{array}$ & 2018 & 355 & 14 & İİBF \\
\hline $\begin{array}{l}\text { Maliyet Muhasebesi } \\
\text { II }\end{array}$ & 1 & & & $\begin{array}{c}\text { Atatürk } \\
\text { Üniversitesi }\end{array}$ & 2014 & 297 & 14 & İ̈BF \\
\hline Maliyet Yönetimi & 1 & 1 & & $\begin{array}{c}\text { Anadolu } \\
\text { Üniversitesi }\end{array}$ & 2019 & 264 & 8 & İİBF \\
\hline Muhasebe Denetimi & 1 & & & $\begin{array}{c}\text { Atatürk } \\
\text { Üniversitesi }\end{array}$ & 2019 & 297 & 14 & İİBF \\
\hline $\begin{array}{l}\text { Muhasebede Bilgi } \\
\text { Yönetimi }\end{array}$ & 1 & 1 & & $\begin{array}{c}\text { Anadolu } \\
\text { Üniversitesi }\end{array}$ & 2019 & 169 & 8 & İİBF \\
\hline Şirketler Muhasebesi & & & & $\begin{array}{c}\text { Atatürk } \\
\text { Üniversitesi }\end{array}$ & 2013 & 325 & 14 & $\begin{array}{l}\text { İ̈BF / Sosyal } \\
\text { Bilimler MYO }\end{array}$ \\
\hline $\begin{array}{c}\text { Muhasebe } \\
\text { Uygulamaları }\end{array}$ & 1 & & & $\begin{array}{c}\text { Anadolu } \\
\text { Üniversitesi }\end{array}$ & 2018 & 210 & 8 & İİBF \\
\hline Genel Muhasebe & 1 & & & $\begin{array}{l}\text { Anadolu } \\
\text { Üniversitesi }\end{array}$ & 2018 & 197 & 8 & $\begin{array}{c}\text { İIBF / Sosyal } \\
\text { Bilimler MYO / } \\
\text { Sağlık Hizmetleri } \\
\text { MYO / Lisans } \\
\text { Tamamlama }\end{array}$ \\
\hline Envanter ve Bilanço & 1 & & 1 & $\begin{array}{c}\text { Anadolu } \\
\text { Üniversitesi }\end{array}$ & 2020 & 191 & 8 & $\begin{array}{c}\text { İ̈BF/ Sosyal } \\
\text { Bilimler MYO }\end{array}$ \\
\hline Muhasebe Denetimi & 1 & & & $\begin{array}{c}\text { Anadolu } \\
\text { Üniversitesi }\end{array}$ & 2018 & 162 & 8 & $\begin{array}{c}\text { İ̈B / Sosyal } \\
\text { Bilimler MYO }\end{array}$ \\
\hline Şirketler Muhasebesi & 1 & & & $\begin{array}{c}\text { Anadolu } \\
\text { Üniversitesi }\end{array}$ & 2019 & 229 & 8 & $\begin{array}{c}\text { İ̈BF / Sosyal } \\
\text { Bilimler MYO }\end{array}$ \\
\hline $\begin{array}{c}\text { Diş Ticaret } \\
\text { İşlemlerinin } \\
\text { Muhasebeleştirilmesi }\end{array}$ & 1 & & & $\begin{array}{l}\text { Anadolu } \\
\text { Üniversitesi }\end{array}$ & 2019 & 258 & 8 & $\begin{array}{l}\text { İ̈BF / Sosyal } \\
\text { Bilimler MYO }\end{array}$ \\
\hline $\begin{array}{c}\text { Lojistik Maliyetleri } \\
\text { ve Raporlama }\end{array}$ & 1 & & & $\begin{array}{c}\text { Anadolu } \\
\text { Üniversitesi }\end{array}$ & 2020 & 224 & 8 & İİBF \\
\hline $\begin{array}{c}\text { Lojistik Maliyetleri } \\
\text { ve } \\
\text { Raporlama I }\end{array}$ & 1 & & 1 & $\begin{array}{l}\text { Anadolu } \\
\text { Üniversitesi }\end{array}$ & 2018 & 200 & 8 & $\begin{array}{l}\text { İİBF / Sosyal } \\
\text { Bilimler MYO }\end{array}$ \\
\hline $\begin{array}{c}\text { Lojistik Maliyetleri } \\
\text { ve Raporlama II }\end{array}$ & 1 & & 1 & $\begin{array}{c}\text { Anadolu } \\
\text { Üniversitesi }\end{array}$ & 2019 & 235 & 8 & $\begin{array}{c}\text { İ̈BF / Sosyal } \\
\text { Bilimler MYO }\end{array}$ \\
\hline $\begin{array}{l}\text { Muhasebe } \\
\text { Yazılimları }\end{array}$ & & 1 & & $\begin{array}{c}\text { Anadolu } \\
\text { Üniversitesi }\end{array}$ & 2019 & 252 & 8 & $\begin{array}{c}\text { İBF / Sosyal } \\
\text { Bilimler MYO }\end{array}$ \\
\hline Banka Muhasebesi & 1 & & & $\begin{array}{c}\text { Atatürk } \\
\text { Üniversitesi }\end{array}$ & 2014 & 278 & 14 & $\begin{array}{c}\text { Sosyal Bilimler } \\
\text { MYO }\end{array}$ \\
\hline $\begin{array}{c}\text { Banka ve Sigorta } \\
\text { Muhasebesi }\end{array}$ & 1 & & & $\begin{array}{c}\text { Anadolu } \\
\text { Üniversitesi }\end{array}$ & 2019 & 260 & 8 & $\begin{array}{c}\text { Sosyal Bilimler } \\
\text { MYO }\end{array}$ \\
\hline Sigorta Muhasebesi & 1 & & & $\begin{array}{c}\text { Atatürk } \\
\text { Üniversitesi }\end{array}$ & 2014 & 262 & 14 & $\begin{array}{c}\text { Sosyal Bilimler } \\
\text { MYO }\end{array}$ \\
\hline
\end{tabular}


ÇAVUŞOĞLU

\begin{tabular}{|c|c|c|c|c|c|c|c|c|}
\hline $\begin{array}{l}\text { Ön Muhasebe } \\
\text { Yazılımları } \\
\text { Ve Kullanımı }\end{array}$ & & & 1 & $\begin{array}{c}\text { Anadolu } \\
\text { Üniversitesi }\end{array}$ & 2018 & 170 & 6 & $\begin{array}{l}\text { Sosyal Bilimler } \\
\text { MYO }\end{array}$ \\
\hline $\begin{array}{l}\text { Dış Ticaret İşlemleri } \\
\text { Muhasebesi }\end{array}$ & 1 & & & $\begin{array}{c}\text { Atatürk } \\
\text { Üniversitesi }\end{array}$ & 2017 & 298 & 14 & $\begin{array}{c}\text { Sosyal Bilimler } \\
\text { MYO }\end{array}$ \\
\hline İnşaat Muhasebesi & 1 & & & $\begin{array}{c}\text { Atatürk } \\
\text { Üniversitesi }\end{array}$ & 2017 & 290 & 14 & $\begin{array}{c}\text { Sosyal Bilimler } \\
\text { MYO }\end{array}$ \\
\hline $\begin{array}{c}\text { İnşaat ve } \\
\text { Gayrimenkul } \\
\text { Muhasebesi }\end{array}$ & 1 & & & $\begin{array}{l}\text { Anadolu } \\
\text { Üniversitesi }\end{array}$ & 2019 & 243 & 8 & $\begin{array}{l}\text { Sosyal Bilimler } \\
\text { MYO }\end{array}$ \\
\hline $\begin{array}{c}\text { Lojistik Maliyet } \\
\text { Analizi }\end{array}$ & 1 & & & $\begin{array}{c}\text { Atatürk } \\
\text { Üniversitesi }\end{array}$ & 2014 & 288 & 14 & $\begin{array}{c}\text { Sosyal Bilimler } \\
\text { MYO }\end{array}$ \\
\hline Maliyet Analizleri & & 1 & & $\begin{array}{c}\text { Anadolu } \\
\text { Üniversitesi }\end{array}$ & 2019 & 211 & 7 & $\begin{array}{c}\text { Sosyal Bilimler } \\
\text { MYO }\end{array}$ \\
\hline Muhasebe Ve Hukuk & 1 & & & $\begin{array}{c}\text { Anadolu } \\
\text { Üniversitesi }\end{array}$ & 2018 & 203 & 8 & $\begin{array}{c}\text { Sosyal Bilimler } \\
\text { MYO }\end{array}$ \\
\hline $\begin{array}{c}\text { Sağlık Kurumlarında } \\
\text { Maliyet } \\
\text { Muhasebesi }\end{array}$ & & & 1 & $\begin{array}{c}\text { Anadolu } \\
\text { Üniversitesi }\end{array}$ & 2018 & 205 & 8 & $\begin{array}{l}\text { Sağllk Bilimleri } \\
\text { Fakültesi }\end{array}$ \\
\hline $\begin{array}{c}\text { Sağlık Kurumlarında } \\
\text { Maliyet } \\
\text { Yönetimi } \\
\end{array}$ & 1 & & & $\begin{array}{l}\text { Atatürk } \\
\text { Üniversitesi }\end{array}$ & 2013 & 301 & 14 & $\begin{array}{l}\text { Sağllk Bilimleri } \\
\text { Fakültesi }\end{array}$ \\
\hline $\begin{array}{l}\text { Konaklama } \\
\text { İşletmelerinde } \\
\text { Muhasebe } \\
\text { Uygulamaları }\end{array}$ & 1 & & & $\begin{array}{c}\text { Anadolu } \\
\text { Üniversitesi }\end{array}$ & 2019 & 259 & 8 & Turizm Fakültesi \\
\hline $\begin{array}{c}\text { Muhasebe Denetimi } \\
\text { ve Mali } \\
\text { Analiz } \\
\end{array}$ & 1 & & & $\begin{array}{l}\text { Anadolu } \\
\text { Üniversitesi }\end{array}$ & 2012 & 159 & 8 & Turizm Fakültesi \\
\hline Denetim & 1 & & & $\begin{array}{c}\text { Anadolu } \\
\text { Üniversitesi }\end{array}$ & 2018 & 237 & 8 & $\begin{array}{c}\text { İ̈BF / Sağllk } \\
\text { Bilimleri Fakültesi }\end{array}$ \\
\hline $\begin{array}{c}\text { Sağlık Kurumlarında } \\
\text { Maliyet } \\
\text { Yönetimi } \\
\end{array}$ & & 1 & & $\begin{array}{c}\text { Anadolu } \\
\text { Üniversitesi }\end{array}$ & 2019 & 238 & 8 & $\begin{array}{c}\text { Sağlık Hizmetleri } \\
\text { MYO }\end{array}$ \\
\hline $\begin{array}{c}\text { Finansal Tablolar } \\
\text { Analizi }\end{array}$ & 1 & & & $\begin{array}{c}\text { Anadolu } \\
\text { Üniversitesi }\end{array}$ & 2019 & 220 & 8 & $\begin{array}{l}\text { İ̈BF / Lisans } \\
\text { Tamamlama }\end{array}$ \\
\hline $\begin{array}{l}\text { Mali Tablolar } \\
\text { Analizi }\end{array}$ & 1 & & & $\begin{array}{c}\text { Atatürk } \\
\text { Üniversitesi }\end{array}$ & 2018 & 293 & 14 & $\begin{array}{l}\text { İ̈BF / Sosyal } \\
\text { Bilimler MYO }\end{array}$ \\
\hline Mali Analiz & 1 & & & $\begin{array}{c}\text { Anadolu } \\
\text { Üniversitesi }\end{array}$ & 2019 & 185 & 8 & $\begin{array}{l}\text { İ̈BF / Sosyal } \\
\text { Bilimler MYO }\end{array}$ \\
\hline TOPLAM & 35 & 6 & 5 & & & 10065 & 402 & \\
\hline
\end{tabular}

Tablo 1 incelendiğinde sayfa sayısı bakımından Muhasebe Denetimi ve Mali Analiz (Anadolu Üni.) kitabının minimum sayfa sayısına (159 sayfa), Maliyet Muhasebesi I (Atatürk Üniversitesi) kitabının maksimum sayfa sayısına (355 sayfa) sahip olduğu, kitap başına düşen ortalama sayfa sayısının ise 245,48 (10065/41) olduğu görülmektedir.

Editörlerin unvanlarına bakıldığında en fazla 'Prof. Dr.' unvanlı editörlerin (35) olduğu, bunu sırasıyla 'Doç. Dr.' unvanlı editörlerin (6) ve 'Dr. Öğr. Üye.' unvanlı editörlerin (5) takip ettiği görülmektedir.

Yayınevi dağılımı açısından 41 kitabın 28 tanesinin yayınevi Anadolu Üniversitesi iken, 13 tanesinin yayınevi Atatürk Üniversitesi'dir. Tablo 1'deki bulgular yayın yılı açısından 
değerlendirildiğinde 15 kitapla 2019 yılında en fazla sayıda kitap bulunurken, birer kitap ile en az sayıda kitap 2011 ve 2012 yıllarındadır.

Tablo 1'e göre İktisadi ve İdari Bilimler Fakültesi'nde (İ̈BF) 26 kitap, Sosyal Bilimler MYO'da 25 kitap, Sağlık Bilimleri Fakültesi'nde 6 kitap, Turizm Fakültesi'nde 4 kitap, Lisans Tamamlama'da 4 kitap, Sağlık Hizmetleri MYO'da 3 kitap ve Adalet MYO'da ise 1 kitap açık erişime sunulmuştur. Bölüm sayısı açısından tüm muhasebe kitaplarında toplam 402 bölüm olduğu ve 8 bölüme sahip 25 kitap, 14 bölüme sahip 13 kitap, 7 bölüme sahip 2 kitap ve 6 bölüme sahip 1 kitap olduğu görülmektedir. Bölüm başına ortalama sayfa sayısı ise 25,03'tür (10065/402).

\subsubsection{Muhasebe Kategorilerine İlişkin Bulgular}

Her bir muhasebe kategorisinde yer alan muhasebe kitapları için bulgular ayrı ayrı açıklanmıştır.

\subsubsection{Genel Muhasebe Kategorisine İlişkin Bulgular}

Genel muhasebe kategorisinde yer alan kitaplara ait bölüm sayfa sayısı bilgileri verildikten sonra, yararlanılan kaynak sayısına, kaynak diline, kaynak türüne* ve kaynak yayın yılına ${ }^{\dagger}$ göre kitaplarının dağılımına ait bulgular sunulmuştur.

Tablo 2. Genel Muhasebe Kategorisindeki Kitapların Bölüm Yazar Unvanları ile Sayfa Sayıları

\begin{tabular}{|c|c|c|c|c|c|c|c|c|c|c|}
\hline \multirow[b]{2}{*}{$\begin{array}{l}\text { Kitap Adı } \\
\text { (Yayınevi) }\end{array}$} & \multirow[b]{2}{*}{$\begin{array}{l}\text { Bölüm } \\
\text { Sayısı }\end{array}$} & \multicolumn{6}{|c|}{ Bölüm Yazar Unvanları } & \multicolumn{3}{|c|}{ Bölüm Sayfa Sayısı } \\
\hline & & 官 & $\begin{array}{l}\dot{\vec{\rho}} \\
\stackrel{0}{\circ}\end{array}$ & 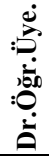 & مُّن & مَّة: & $\dot{\vec{\theta}}$ & 声 & 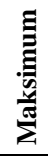 & 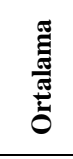 \\
\hline Genel Muhasebe (Atatürk Üni.) & 14 & 14 & 0 & 0 & 0 & 0 & 0 & 17 & 30 & 24,35 \\
\hline Genel Muhasebe I (Anadolu Üni.) & 8 & 8 & 0 & 0 & 0 & 0 & 0 & 18 & 31 & 24,12 \\
\hline $\begin{array}{l}\text { Genel Muhasebe II (Anadolu } \\
\text { Uni.) }\end{array}$ & 7 & 7 & 0 & 0 & 0 & 0 & 0 & 19 & 26 & 23,28 \\
\hline Genel Muhasebe (Anadolu Üni) & 8 & 8 & 0 & 0 & 0 & 0 & 0 & 18 & 32 & 23,75 \\
\hline TOPLAM & 37 & 37 & $\mathbf{0}$ & $\mathbf{0}$ & $\mathbf{0}$ & $\mathbf{0}$ & 0 & & & \\
\hline
\end{tabular}

Genel muhasebe kategorisinde 3'ü Anadolu Üniversitesi'ne 1'i Atatürk Üniversitesi'ne ait olmak üzere toplam 4 kitap bulunmaktadır. Kitaplardaki toplam bölüm sayısı 37'dir. Bölüm yazarlarının tümü, 'Prof.Dr.'unvanlıdır (37). Dört kitap içinde 17 sayfa ile Genel Muhasebe (Atatürk Üni.) kitabındaki 'İşletme ve Muhasebe' adlı bölüm en düşük minimum bölüm sayfa sayısına, 32 sayfa ile Genel Muhasebe (Anadolu Üni.) kitabındaki ‘Dönen Varlıklar' adlı bölüm en yüksek maksimum bölüm sayfa sayısına sahiptir. Dört kitabın ortalama bölüm sayfa sayılarının birbirine yakın olduğu görülmektedir.

\footnotetext{
* Tablolarda kaynak türü olarak yer alan diğer kaynaklar; ders slaytı, ders notları, eğitim ders notları, çalışma kağıtları, rapor gibi kaynakları ifade etmektedir.

† Yayınların kaynakçalarında bazı kaynakların yayın yılları belirtilmediğinden, tablolarda kaynak yayın yılına göre kaynak sayısı toplamı, toplam kaynak sayısından düşük çıkabilmektedir.
} 
Tablo 3. Genel Muhasebe Kategorisindeki Kitapların Kaynak Sayısına, Diline, Türüne ve Yayın Yılına göre Dağılımı

\begin{tabular}{|c|c|c|c|c|c|c|c|c|c|c|c|c|c|c|c|}
\hline \multirow[b]{2}{*}{$\begin{array}{l}\text { Kitap Adı } \\
\text { (Yayınevi) }\end{array}$} & \multirow[b]{2}{*}{ 㓂 } & \multicolumn{2}{|c|}{ Kaynak Dili } & \multicolumn{7}{|c|}{ Kaynak Türü } & \multicolumn{5}{|c|}{ Kaynak Yayın Yılı } \\
\hline & & 离 & 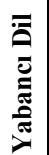 & 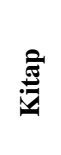 & 苞 & & & ": & $\stackrel{\nabla}{\oplus}$ & 总 & 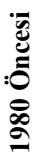 & 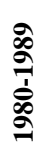 & 亏ิ & 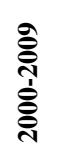 & $\begin{array}{l}\text { तิ } \\
\text { ஸิ } \\
\text { હิ }\end{array}$ \\
\hline $\begin{array}{c}\text { Genel } \\
\text { Muhasebe } \\
\text { (Atatürk Üni.) }\end{array}$ & 140 & 133 & 7 & 117 & 1 & 12 & 0 & 0 & 0 & 10 & 3 & 5 & 28 & 64 & 25 \\
\hline \begin{tabular}{|c|} 
Genel \\
Muhasebe I \\
(Anadolu Üni.)
\end{tabular} & 53 & 53 & 0 & 34 & 2 & 8 & 8 & 1 & 0 & 0 & 1 & 0 & 7 & 16 & 17 \\
\hline $\begin{array}{c}\text { Genel } \\
\text { Muhasebe II } \\
\text { (Anadolu Uni.) }\end{array}$ & 56 & 56 & 0 & 42 & 2 & 9 & 2 & 0 & 0 & 1 & 0 & 0 & 8 & 19 & 20 \\
\hline \begin{tabular}{|c|} 
Genel \\
Muhasebe \\
(Anadolu Üni)
\end{tabular} & 46 & 45 & 1 & 44 & 0 & 2 & 0 & 0 & 0 & 0 & 1 & 0 & 5 & 23 & 16 \\
\hline TOPLAM & 295 & 287 & 8 & 237 & 5 & 31 & 10 & 1 & $\mathbf{0}$ & 11 & 5 & 5 & 48 & 122 & 78 \\
\hline
\end{tabular}

Tablo 3'e bakıldığında genel muhasebe kategorisindeki kitaplarda yararlanılan toplam kaynak sayısının 295 olduğu görülmektedir. Kitap başına 73,75 (295/4) kaynak düşerken, bölüm başına 7,97 (295/37) kaynak düşmektedir. 295 kaynağın 287'si $(\% 97,29)$ Türkçe olup, yalnızca 8'i $(\% 2,71)$ yabancı dildedir. Kaynak türü açısından en fazla yararlanılan kaynak; 237 kaynak sayısı $(\% 80,34)$ ile kitap olurken, bunu sirasıyla 31 kaynak sayısıyla $(\% 10,50)$ mevzuat, 11 kaynak sayısıyla $(\% 3,73)$ diğer kaynaklar, 10 kaynak sayısıyla $(\% 3,39)$ internet, 5 kaynak sayısıyla $(\% 1,70)$ dergi, 1 kaynak sayısı ile bildiri $(\% 0,34)$ izlemektedir. Tez türünde ise hiçbir kaynaktan faydalanılmamıştır. Kaynakların yayın yılı dağılımı incelendiğinde 122 kaynak sayısı (\%47,29) ile en fazla 2000-2009 dönemine ait kaynağın kullanıldığı, bunu sirasıyla 78 kaynak sayısı (\%30,23) ile 2010-2020 döneminin, 48 kaynak sayısıyla (\%18,60) 1990-1999 döneminin, 5'er kaynak sayıları $(\% 1,94)$ ile 1980-1989 ve 1980 öncesi dönemin takip ettiği görülmektedir.

\subsubsection{Dönem Sonu Muhasebesine İlişkin Bulgular}

Dönem sonu muhasebesi kategorisinde yer alan kitaplara ait bölüm sayfa sayısı bilgileri verildikten sonra, yararlanılan kaynak sayısına, kaynak diline, kaynak türüne ve kaynak yılına göre kitaplarının dağılımına ait bulgular sunulmuştur. 
Tablo 4. Dönem Sonu Muhasebesi Kategorisindeki Kitapların Bölüm Yazar Unvanları ile Sayfa Sayıları

\begin{tabular}{|c|c|c|c|c|c|c|c|c|c|c|}
\hline \multirow[b]{2}{*}{$\begin{array}{l}\text { Kitap Adı } \\
\text { (Yayınevi) }\end{array}$} & \multirow[b]{2}{*}{$\begin{array}{l}\text { Bölüm } \\
\text { Sayısı }\end{array}$} & \multicolumn{6}{|c|}{ Bölüm Yazar Unvanları } & \multicolumn{3}{|c|}{ Bölüm Sayfa Sayısı } \\
\hline & & $\begin{array}{l}\dot{\vec{\Delta}} \\
\stackrel{\Delta}{\circ}\end{array}$ & $\begin{array}{l}\dot{\vec{\Delta}} \\
\stackrel{.}{\circ}\end{array}$ & 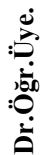 & مُّن: & مَّْ: & $\dot{\vec{\Delta}}$ & 跑 & 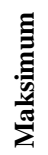 & \\
\hline $\begin{array}{l}\text { Dönem Sonu Muhasebe } \\
\text { İşlemleri (Atatürk Üni.) }\end{array}$ & 14 & 13 & 1 & 0 & 0 & 0 & 0 & 18 & 31 & 22,42 \\
\hline \begin{tabular}{|c|} 
Dönemsonu İşlemleri (Anadolu \\
Üni.)
\end{tabular} & 8 & 4 & 0 & 3 & 0 & 0 & 1 & 24 & 40 & 30,37 \\
\hline $\begin{array}{c}\text { Envanter ve Bilanço (Anadolu } \\
\text { Üni.) }\end{array}$ & 8 & 7 & 0 & 0 & 1 & 0 & 0 & 16 & 32 & 22,50 \\
\hline TOPLAM & 30 & 24 & 1 & 3 & 1 & $\begin{array}{l}\mathbf{0} \\
\end{array}$ & 1 & & & \\
\hline
\end{tabular}

Dönem sonu muhasebe kategorisinde 2'si Anadolu Üniversitesi'ne, 1'i Atatürk Üniversitesi'ne ait olmak üzere 3 kitap bulunmaktadır. Kitaplardaki toplam bölüm sayıs1 30'dur. Unvan açısından en fazla 'Prof. Dr.' unvanlı (24) bölüm yazarı olduğu, bunu sırasıyla 'Dr. Öğr. Üye' unvanlı (3), 'Doç.Dr.' unvanlı (1), 'Öğr. Gör. Dr' unvanlı (1) ve 'Dr.' unvanlı (1) yazarların takip ettiği görülmektedir. Üç kitap içinde 16 sayfa ile Envanter ve Bilanço (Anadolu Üni.) kitabındaki 'Muhasebede Değerleme' adlı bölüm en düşük minimum bölüm sayfa sayısına, 40 sayfa ile Dönemsonu İşlemleri (Anadolu Üni.) kitabındaki 'Hazır Değerler ve Menkul Kıymetlere İlişkin Dönemsonu İşlemleri' adlı bölüm en yüksek maksimum bölüm sayfa sayısına sahiptir. Tablo 4'te görüldüğü gibi Dönemsonu İşlemleri (Anadolu Üni.) kitabının ortalama bölüm sayfa sayısı 30,37 iken, diğer iki kitabın ortalama bölüm sayfa sayıları birbirine yakındır.

Tablo 5. Dönem Sonu Muhasebesi Kategorisindeki Kitapların Kaynak Sayısına, Diline, Türüne ve Yayın Yılına göre Dağılımı

\begin{tabular}{|c|c|c|c|c|c|c|c|c|c|c|c|c|c|c|c|}
\hline \multirow[b]{2}{*}{$\begin{array}{l}\text { Kitap Adı } \\
\text { (Yayınevi) }\end{array}$} & \multirow[b]{2}{*}{ 㮍 } & \multicolumn{2}{|c|}{$\begin{array}{c}\text { Kaynak } \\
\text { Dili }\end{array}$} & \multicolumn{7}{|c|}{ Kaynak Türü } & \multicolumn{5}{|c|}{ Kaynak Yayın Yılı } \\
\hline & & 莣 & 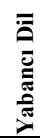 & స्ञิ & 范 & 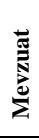 & .ֶّ & : & $\stackrel{\Xi}{=}$ & 苟 & 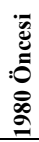 & $\begin{array}{l}\stackrel{\circ}{\circ} \\
\frac{1}{\circ} \\
\stackrel{2}{\sigma}\end{array}$ & $\begin{array}{l}\frac{\hat{\sigma}}{\hat{\sigma}} \\
\text { बे }\end{array}$ & 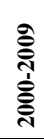 & ָิ̃ \\
\hline $\begin{array}{l}\text { Dönem Sonu } \\
\text { Muhasebe } \\
\text { İşlemleri } \\
\text { (Atatürk Üni.) }\end{array}$ & 124 & 117 & 7 & 113 & 1 & 8 & 2 & 0 & 0 & 0 & 3 & 9 & 16 & 52 & 34 \\
\hline $\begin{array}{c}\text { Dönemsonu } \\
\text { İşlemleri } \\
\text { (Anadolu Üni.) }\end{array}$ & 79 & 69 & 10 & 53 & 3 & 11 & 12 & 0 & 0 & 0 & 0 & 0 & 2 & 14 & 46 \\
\hline $\begin{array}{c}\text { Envanter ve } \\
\text { Bilanço (Anadolu } \\
\text { Üni.) } \\
\end{array}$ & 64 & 64 & 0 & 40 & 5 & 10 & 6 & 1 & 1 & 1 & 0 & 1 & 9 & 21 & 18 \\
\hline TOPLAM & 267 & 250 & 17 & 206 & 9 & 29 & 20 & 1 & 1 & 1 & 3 & 10 & 27 & 87 & 98 \\
\hline
\end{tabular}

Tablo 5'e göre dönem sonu muhasebesi kategorisindeki kitaplarda yararlanılan toplam kaynak sayısı 267'dir. Kitap başına 89 (267/3) kaynak düşerken, bölüm başına 8,9 (267/30) kaynak düşmektedir. 267 kaynağın 250'si $(\% 93,63)$ Türkçe olup, yalnızca 17'si $(\% 6,37)$ yabancı dildedir. Kaynak türü açısından en fazla yararlanılan kaynak; 206 kaynak sayısıyla $(\% 77,15)$ kitap olurken, bunu 29 kaynak sayısıyla $(\% 10,87)$ mevzuat, 20 kaynak sayısıla $(\% 7,50)$ internet, 9 kaynak sayısıyla $(\% 3,37)$ dergi, 1 'er kaynak sayısıyla $(\% 0,37)$ bildiri, tez ve diğer kaynaklar takip etmektedir. Kaynakların yayın yılı dağılımına bakıldığında 98 kaynak sayısı 
$(\% 43,56)$ ile en fazla 2010-2020 dönemine ait kaynağın kullanıldı̆̆ sayısıyla (\%38,67) 2000-2009 döneminin, 27 kaynak sayısıyla (\%12) 1990-1999 döneminin, 10 kaynak sayısıyla $(\% 4,44)$ 1980-1989 döneminin ve 3 kaynak sayısıyla $(\% 1,33) 1980$ öncesi dönemin izlediği görülmektedir.

\subsubsection{Yönetim/Maliyet Muhasebesi Kategorisine İlişkin Bulgular}

Yönetim/maliyet muhasebesi kategorisinde yer alan kitaplara ait bölüm sayfa sayısı bilgileri verildikten sonra, yararlanılan kaynak sayısına, kaynak diline, kaynak türüne ve kaynak yılına göre kitaplarının dağılımına ait bulgular sunulmuştur.

Tablo 6. Yönetim/Maliyet Muhasebesi Kategorisindeki Kitapların Bölüm Yazar Unvanları ile Sayfa Sayıları

\begin{tabular}{|c|c|c|c|c|c|c|c|c|c|c|}
\hline \multirow[b]{2}{*}{$\begin{array}{l}\text { Kitap Adı } \\
\text { (Yayınevi) }\end{array}$} & \multirow[b]{2}{*}{$\begin{array}{l}\text { Bölüm } \\
\text { Sayısı }\end{array}$} & \multicolumn{6}{|c|}{ Bölüm Yazar Unvanları } & \multicolumn{3}{|c|}{ Bölüm Sayfa Sayısı } \\
\hline & & تُّ & $\begin{array}{l}\dot{\vec{\theta}} \\
\dot{\leftrightarrow}\end{array}$ & 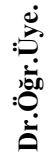 & مُ & 苛 & $\dot{\vec{\theta}}$ & 声 & 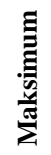 & 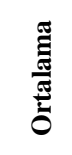 \\
\hline $\begin{array}{l}\text { Maliyet Muhasebesi (Anadolu } \\
\text { Üni.) }\end{array}$ & 8 & 1 & 7 & 0 & 0 & 0 & 0 & 32 & 44 & 35,37 \\
\hline $\begin{array}{l}\text { Maliyet Muhasebesi I (Atatürk } \\
\text { Üni.) }\end{array}$ & 14 & 3 & 8 & 3 & 0 & 0 & 0 & 17 & 38 & 25,14 \\
\hline $\begin{array}{l}\text { Maliyet Muhasebesi II } \\
\text { (Atatürk Üni.) }\end{array}$ & 14 & 8 & 1 & 5 & 0 & 0 & 0 & 17 & 28 & 21 \\
\hline $\begin{array}{c}\text { Maliyet Yönetimi (Anadolu } \\
\text { Üni.) }\end{array}$ & 8 & 4 & 4 & 0 & 0 & 0 & 0 & 22 & 53 & 31,62 \\
\hline $\begin{array}{c}\text { Lojistik Maliyetleri ve } \\
\text { Raporlama (Anadolu Üni.) }\end{array}$ & 8 & 8 & 0 & 0 & 0 & 0 & 0 & 16 & 34 & 26,25 \\
\hline $\begin{array}{c}\text { Lojistik Maliyetleri ve } \\
\text { Raporlama I (Anadolu Üni.) }\end{array}$ & 8 & 9 & 0 & 0 & 0 & 0 & 0 & 22 & 28 & 24,12 \\
\hline $\begin{array}{c}\text { Lojistik Maliyetleri ve } \\
\text { Raporlama II (Anadolu Üni.) }\end{array}$ & 8 & 7 & 1 & 1 & 0 & 0 & 0 & 24 & 35 & 28,12 \\
\hline $\begin{array}{l}\text { Lojistik Maliyet Analizi } \\
\text { (Atatürk Üni.) }\end{array}$ & 14 & 14 & 0 & 0 & 0 & 0 & 0 & 15 & 27 & 20,35 \\
\hline $\begin{array}{c}\text { Maliyet Analizleri (Anadolu } \\
\text { Üni.) }\end{array}$ & 7 & 3 & 4 & 0 & 0 & 0 & 0 & 24 & 34 & 28,85 \\
\hline $\begin{array}{l}\text { Sağllk Kurumlarında Maliyet } \\
\text { Muhasebesi (Anadolu Üni.) }\end{array}$ & 8 & 4 & 0 & 2 & 2 & 0 & 0 & 20 & 28 & 24,25 \\
\hline $\begin{array}{l}\text { Sağllk Kurumlarında Maliyet } \\
\text { Yönetimi (Atatürk Üni.) }\end{array}$ & 14 & 11 & 3 & 0 & 0 & 0 & 0 & 17 & 25 & 21,28 \\
\hline $\begin{array}{l}\text { Sağlık Kurumlarında Maliyet } \\
\text { Yönetimi (Anadolu Üni.) }\end{array}$ & 8 & 8 & 0 & 0 & 0 & 0 & 0 & 24 & 36 & 28,37 \\
\hline TOPLAM & 119 & 80 & 28 & 11 & 2 & 0 & $\mathbf{0}$ & & & \\
\hline
\end{tabular}

Yönetim/maliyet muhasebesi kategorisinde 8'i Anadolu Üniversitesi'ne, 4'ü Atatürk Üniversitesi'ne ait olmak üzere 12 kitap bulunmaktadır. Kitaplardaki toplam bölüm sayısı 119 'dur. Unvan açısından en fazla 'Prof.Dr.' unvanlı (80) bölüm yazarı olduğu, bunu sirasıyla 'Doç. Dr.' unvanlı (28), 'Dr. Öğr. Üye’ unvanlı (11), 'Öğr. Gör. Dr.' unvanlı (2) yazarların takip ettiği görülmektedir. On iki kitap içerisinde 15 sayfa ile Lojistik Maliyet Analizi (Atatürk Üni.) kitabındaki 'Genel Olarak Maliyet Hesaplama Yöntemleri' bölümü en düşük minimum bölüm sayfa sayısına, 53 sayfa ile Maliyet Yönetimi (Anadolu Üni.) kitabındaki 'Stratejik Maliyet Yönetimi' bölümü en yüksek maksimum bölüm sayfa sayısına sahiptir. Maliyet Muhasebesi (Anadolu Üni.) kitabı, en yüksek ortalama bölüm sayfa sayısına $(35,37)$ sahiptir. 
Tablo 7a. Yönetim/Maliyet Muhasebesi Kategorisindeki Kitapların Kaynak Sayısına, Diline,

Türüne ve Yayın Yılına göre Dağılımı

\begin{tabular}{|c|c|c|c|c|c|c|c|c|c|c|}
\hline \multirow[b]{2}{*}{$\begin{array}{l}\text { Kitap Adı } \\
\text { (Yayınevi) }\end{array}$} & \multirow[b]{2}{*}{ 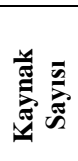 } & \multicolumn{2}{|c|}{ Kaynak Dili } & \multicolumn{7}{|c|}{ Kaynak Türü } \\
\hline & & 莣 & 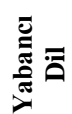 & 气ิ & 预 & 离 & 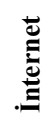 & : & $\stackrel{\mathbb{N}}{\stackrel{N}{*}}$ & 离 \\
\hline $\begin{array}{c}\begin{array}{c}\text { Maliyet Muhasebesi } \\
\text { (Anadolu Üni.) }\end{array} \\
\end{array}$ & 191 & 144 & 47 & 176 & 10 & 0 & 2 & 1 & 2 & 0 \\
\hline \begin{tabular}{|c|}
$\begin{array}{c}\text { Maliyet Muhasebesi I } \\
\text { (Atatürk Üni.) }\end{array}$ \\
\end{tabular} & 122 & 107 & 15 & 100 & 11 & 4 & 5 & 0 & 1 & 1 \\
\hline $\begin{array}{c}\text { Maliyet Muhasebesi II } \\
\text { (Atatürk Üni.) }\end{array}$ & 205 & 181 & 24 & 149 & 41 & 2 & 8 & 1 & 4 & 0 \\
\hline $\begin{array}{l}\text { Maliyet Yönetimi } \\
\text { (Anadolu Üni.) }\end{array}$ & 223 & 136 & 87 & 186 & 20 & 0 & 3 & 0 & 5 & 9 \\
\hline \begin{tabular}{|c} 
Lojistik Maliyetleri ve \\
Raporlama (Anadolu \\
Üni.)
\end{tabular} & 166 & 117 & 49 & 61 & 58 & 6 & 22 & 7 & 11 & 1 \\
\hline $\begin{array}{l}\text { Lojistik Maliyetleri ve } \\
\text { Raporlama I (Anadolu } \\
\text { Üni.) }\end{array}$ & 125 & 78 & 47 & 67 & 30 & 0 & 14 & 3 & 9 & 2 \\
\hline $\begin{array}{l}\text { Lojistik Maliyetleri ve } \\
\text { Raporlama II (Anadolu } \\
\text { Üni.) }\end{array}$ & 130 & 94 & 36 & 30 & 41 & 2 & 26 & 3 & 19 & 9 \\
\hline $\begin{array}{c}\text { Lojistik Maliyet } \\
\text { Analizi (Atatürk Üni.) }\end{array}$ & 201 & 111 & 90 & 111 & 50 & 1 & 8 & 2 & 24 & 5 \\
\hline $\begin{array}{l}\text { Maliyet Analizleri } \\
\text { (Anadolu Üni.) }\end{array}$ & 104 & 93 & 11 & 103 & 0 & 1 & 0 & 0 & 0 & 0 \\
\hline $\begin{array}{l}\text { Sağllk Kurumlarında } \\
\text { Maliyet Muhasebesi } \\
\text { (Anadolu Üni.) }\end{array}$ & 124 & 122 & 2 & 81 & 39 & 0 & 0 & 0 & 4 & 0 \\
\hline $\begin{array}{c}\text { Sağlik Kurumlarında } \\
\text { Maliyet Yönetimi } \\
\text { (Atatürk Üni.) } \\
\end{array}$ & 145 & 125 & 20 & 88 & 27 & 9 & 5 & 2 & 10 & 4 \\
\hline \begin{tabular}{|c|} 
Sağllk Kurumlarında \\
Maliyet Yönetimi \\
(Anadolu Üni.)
\end{tabular} & 69 & 57 & 12 & 58 & 5 & 0 & 2 & 4 & 0 & 0 \\
\hline TOPLAM & 1805 & 1365 & 440 & 1210 & 332 & 25 & 95 & 23 & 89 & 31 \\
\hline
\end{tabular}

Tablo 7a'ye göre yönetim/maliyet muhasebesi kategorisindeki kitaplarda yararlanılan toplam kaynak sayıs 1.805 'tir. Kitap başına 150,41 (1.805/12) kaynak düşerken, bölüm başına ise $15,16(1.805 / 119)$ kaynak düşmektedir. 1.805 kaynağın 1.365'i $(\% 75,62)$ Türkçe olup, 440'1 $(\% 24,38)$ ise yabancı dildedir. Kaynak türü açısından en fazla yararlanılan kaynak; 1.210 kaynak sayısı $(\% 67,03)$ ile kitap olurken, bunu sırasıyla 332 kaynak sayısıyla $(\% 18,40)$ dergi, 95 kaynak sayısıyla $(\% 5,26)$ internet, 89 kaynak sayısıyla $(\% 4,93)$ tez, 31 kaynak sayısıyla $(1,71)$ diğer kaynaklar, 25 kaynak sayısıyla $(\% 1,39)$ mevzuat ve 23 kaynak sayısıyla $(\% 1,28)$ bildiri izlemektedir. 
Tablo 7b. Yönetim/Maliyet Muhasebesi Kategorisindeki Kitapların Kaynak Yayın Yılına göre Dağılımı

\begin{tabular}{|c|c|c|c|c|c|}
\hline \multirow[b]{2}{*}{$\begin{array}{l}\text { Kitap Adı } \\
\text { (Yayınevi) }\end{array}$} & \multicolumn{5}{|c|}{ Kaynak Yayın Yılı } \\
\hline & \&્ळ & $\begin{array}{l}\stackrel{\circ}{\circ} \\
\text { ळे }\end{array}$ & $\begin{array}{l}\hat{\sigma} \\
\text { ڤ̆ }\end{array}$ & 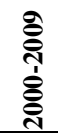 & 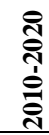 \\
\hline Maliyet Muhasebesi (Anadolu Üni.) & 1 & 17 & 59 & 96 & 18 \\
\hline Maliyet Muhasebesi I (Atatürk Üni.) & 0 & 1 & 22 & 57 & 38 \\
\hline Maliyet Muhasebesi II (Atatürk Üni.) & 1 & 5 & 31 & 112 & 52 \\
\hline Maliyet Yönetimi (Anadolu Üni.) & 8 & 31 & 70 & 79 & 35 \\
\hline $\begin{array}{c}\text { Lojistik Maliyetleri ve Raporlama } \\
\text { (Anadolu Üni.) }\end{array}$ & 1 & 3 & 14 & 72 & 52 \\
\hline $\begin{array}{l}\text { Lojistik Maliyetleri ve Raporlama I } \\
\text { (Anadolu Üni.) }\end{array}$ & 0 & 5 & 31 & 78 & 10 \\
\hline $\begin{array}{l}\text { Lojistik Maliyetleri ve Raporlama II } \\
\text { (Anadolu Üni.) }\end{array}$ & 0 & 2 & 12 & 70 & 38 \\
\hline Lojistik Maliyet Analizi (Atatürk Üni.) & 0 & 8 & 43 & 123 & 26 \\
\hline Maliyet Analizleri (Anadolu Üni.) & 0 & 6 & 20 & 62 & 15 \\
\hline \begin{tabular}{|c} 
Sağlık Kurumlarında Maliyet Muhasebesi \\
(Anadolu Üni.)
\end{tabular} & 0 & 0 & 2 & 61 & 61 \\
\hline $\begin{array}{l}\text { Sağlık Kurumlarında Maliyet Yönetimi } \\
\text { (Atatürk Üni.) }\end{array}$ & 0 & 2 & 25 & 59 & 50 \\
\hline $\begin{array}{l}\text { Sağlık Kurumlarında Maliyet Yönetimi } \\
\text { (Anadolu Üni.) }\end{array}$ & 0 & 0 & 15 & 41 & 13 \\
\hline TOPLAM & 11 & 80 & 344 & 910 & 408 \\
\hline
\end{tabular}

Tablo 7b'ye göre kaynakların yayın yılı dağılımı incelendiğinde 910 kaynak sayısı $(\% 51,91)$ ile en fazla 2000-2009 dönemine ait kaynağın kullanıldığ 1 , bunu sirasıyla 408 kaynak sayısıyla (\%23,28) 2010-2020 döneminin, 344 kaynak sayısıyla (\%19,62) 1990-1999 döneminin, 80 kaynak sayısıyla $(\% 4,57)$ 1980-1989 döneminin ve 11 kaynak sayısıyla $(\% 0,62) 1980$ öncesi dönemin takip ettiği görülmektedir.

\subsubsection{Muhasebe Denetimi Kategorisine İlişkin Bulgular}

Muhasebe denetimi kategorisinde yer alan kitaplara ait bölüm sayfa sayısı bilgileri verildikten sonra, yararlanılan kaynak sayısına, kaynak diline, kaynak türüne ve kaynak yılına göre kitaplarının dağılımına ait bulgular sunulmuştur. 
Tablo 8. Muhasebe Denetimi Kategorisindeki Kitapların Bölüm Yazar Unvanları ile Sayfa Sayıları

\begin{tabular}{|c|c|c|c|c|c|c|c|c|c|c|}
\hline \multirow[b]{2}{*}{$\begin{array}{l}\text { Kitap Adı } \\
\text { (Yayınevi) }\end{array}$} & \multirow[b]{2}{*}{$\begin{array}{l}\text { Bölüm } \\
\text { Sayısı }\end{array}$} & \multicolumn{6}{|c|}{ Bölüm Yazar Unvanları } & \multicolumn{3}{|c|}{ Bölüm Sayfa Sayısı } \\
\hline & & ث̈. & 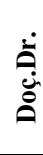 & مُذِّ: & $\begin{array}{l}0 \\
0 \\
0\end{array}$ & مَّْ: & $\dot{\Delta}$ & 䒠 & 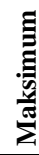 & 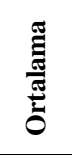 \\
\hline Denetim (Anadolu Üni.) & 8 & 6 & 0 & 1 & 0 & 0 & 0 & 18 & 38 & 28,25 \\
\hline Muhasebe Denetimi (Atatürk Üni.) & 14 & 13 & 1 & 0 & 0 & 0 & 0 & 16 & 27 & 21 \\
\hline Muhasebe Denetimi (Anadolu Üni.) & 8 & 7 & 0 & 1 & 0 & 0 & 0 & 16 & 24 & 19 \\
\hline $\begin{array}{c}\begin{array}{c}\text { Muhasebe Denetimi ve Mali Analiz } \\
\text { (Anadolu Üni.) }\end{array} \\
\end{array}$ & 4 & 3 & 1 & 0 & 0 & 0 & 0 & 18 & 26 & 21,5 \\
\hline TOPLAM & 34 & 29 & 2 & 2 & $\mathbf{0}$ & $\mathbf{0}$ & $\mathbf{0}$ & & & \\
\hline
\end{tabular}

Muhasebe denetimi kategorisinde 3'ü Anadolu Üniversitesi'ne, 1'i Atatürk Üniversitesi'ne ait olmak üzere 4 kitap vardır. Kitaplardaki toplam bölüm sayısı 34'tür. Unvan açısından en fazla 'Prof. Dr.' unvanlı (29) bölüm yazarı olduğu, bunu sırasıyla 'Doç. Dr' unvanlı (2) ve 'Dr. Öğr. Üye' unvanlı (2) bölüm yazarlarının takip ettiği görülmektedir. Bir unvansız bölüm yazarı vardır. Dört kitap içerisinde 16 sayfa ile Muhasebe Denetimi (Atatürk Üni.) kitabındaki 'Çalışma Kağıtları' adlı bölüm ve Muhasebe Denetimi (Anadolu Üni.) kitabındaki 'Muhasebe Denetiminde Örnekleme', 'Bilanço ve Gelir Tablosunun Denetimi' ile 'Denetimin Tamamlanması ve Denetim Raporu’ bölümlerinin en düşük minimum bölüm sayfa sayısına, 38 sayfa ile Denetim (Anadolu Üni.) kitabındaki 'Bilgi Teknolojileri Ortamında Denetim' adlı bölüm en yüksek maksimum bölüm sayfa sayısına sahiptir. Denetim (Anadolu Üni.) kitabı, en yüksek ortalama bölüm sayfa sayısına $(28,25)$ sahiptir.

Tablo 9. Muhasebe Denetimi Kategorisindeki Kitapların Kaynak Sayısına, Diline, Türüne ve Yayın Yılına göre Dağılımı

\begin{tabular}{|c|c|c|c|c|c|c|c|c|c|c|c|c|c|c|c|}
\hline \multirow{2}{*}{$\begin{array}{l}\text { Kitap Adı } \\
\text { (Yayınevi) }\end{array}$} & \multirow[b]{2}{*}{ 泀 } & \multicolumn{2}{|c|}{ Kaynak Dili } & \multicolumn{8}{|c|}{ Kaynak Türü } & \multicolumn{4}{|c|}{ Kaynak Yayın Yılı } \\
\hline & & 总 & 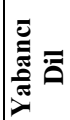 & 产 & 可 & 嶂 & 离 & 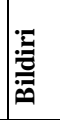 & $\stackrel{Ð}{=}$ & 离 & 离 & 今ั 。े & 亏ิे & 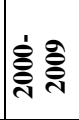 & 을 তิ \\
\hline $\begin{array}{l}\text { Denetim } \\
\text { (Anadolu Üni.) }\end{array}$ & 108 & 68 & 40 & 33 & 21 & 23 & 27 & 1 & 1 & 2 & 0 & 0 & 5 & 47 & 21 \\
\hline \begin{tabular}{|l} 
Muhasebe \\
Denetimi \\
(Atatürk Üni.) \\
\end{tabular} & 221 & 212 & 9 & 140 & 25 & 22 & 26 & 3 & 3 & 2 & 2 & 0 & 40 & 88 & 54 \\
\hline \begin{tabular}{|l|} 
Muhasebe \\
Denetimi \\
(Anadolu Üni.)
\end{tabular} & 44 & 33 & 11 & 36 & 2 & 2 & 3 & 0 & 0 & 1 & 0 & 0 & 10 & 15 & 17 \\
\hline $\begin{array}{l}\text { Muhasebe } \\
\text { Denetimi ve } \\
\text { Mali Analiz } \\
\text { (Anadolu Üni.) } \\
\end{array}$ & 56 & 40 & 16 & 33 & 4 & 1 & 10 & 5 & 0 & 3 & 0 & 1 & 4 & 40 & 7 \\
\hline TOPLAM & 429 & 353 & 76 & 242 & 52 & 48 & 66 & 9 & 4 & 8 & 2 & 1 & 59 & 190 & 99 \\
\hline
\end{tabular}

Tablo 9'a göre muhasebe denetimi kategorisindeki kitaplarda yararlanılan toplam kaynak sayısı 429'dur. Kitap başına 107,25 (429/4) kaynak düşerken, bölüm başına 12,61 (429/34) kaynak

\$ Analizde muhasebe denetimi ile ilgili olan bölümler dikkate alınmıştır. 
düşmektedir. 429 kaynağın 353'ü (\%82,29) Türkçe olup, 76'sı (\%17,71) yabancı dildedir. Kaynak türü açısından en fazla yararlanılan kaynak; 242 kaynak sayısıyla $(\% 56,41)$ kitap olurken, bunu sırasıyla 66 kaynak sayısıyla $(\% 15,39)$ internet, 52 kaynak sayısıyla $(\% 12,12)$ dergi, 48 kaynak sayısıyla $(\% 11,19)$ mevzuat, 9 kaynak sayısıla $(\% 2,10)$ bildiri, 8 kaynak sayısıyla $(\% 1,86)$ diğer kaynaklar ve 4 kaynak sayısıyla $(\% 0,93)$ tez takip etmektedir. Kaynakların yayın yılı dağılımı incelendiğinde 190 kaynak sayısı $(\% 54,14)$ ile en fazla 20002009 dönemine ait kaynağın kullanıldığı, bunu sırasıyla 99 kaynak sayısıyla (\%28,21) 20102020 döneminin, 59 kaynak sayısıyla (\%16,81) 1990-1999 döneminin, 2 kaynak sayısıyla $(\% 0,56) 1980$ öncesi dönemin ve 1 kaynak sayısıyla $(\% 0,28)$ 1980-1989 döneminin takip ettiği görülmektedir.

\subsubsection{Banka/Sigorta Muhasebesi Kategorisine İlişkin Bulgular}

Banka/sigorta muhasebesi kategorisinde yer alan kitaplara ait bölüm sayfa sayısı bilgileri verildikten sonra, yararlanılan kaynak sayısına, kaynak diline, kaynak türüne ve kaynak yılına göre kitaplarının dağılımına ait bulgular sunulmuştur.

Tablo 10. Banka/Sigorta Muhasebe Kategorisindeki Kitapların Bölüm Yazar Unvanları ile Sayfa

\begin{tabular}{|c|c|c|c|c|c|c|c|c|c|c|}
\hline \multirow[b]{3}{*}{$\begin{array}{l}\text { Kitap Adı } \\
\text { (Yaymevi) }\end{array}$} & \multirow[b]{3}{*}{$\begin{array}{c}\text { Bölüm } \\
\text { Sayısı }\end{array}$} & \multicolumn{6}{|c|}{ Sayıları } & \multirow{2}{*}{\multicolumn{3}{|c|}{ Bölüm Sayfa Sayısı }} \\
\hline & & & & a Ya & Unv & & & & & \\
\hline & & بُّ & $\begin{array}{l}\dot{\vec{\theta}} \\
\stackrel{\leftrightarrow}{\circ}\end{array}$ & 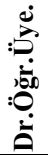 & مُّن: & مَّْ: & $\dot{\vec{\Delta}}$ & 䒠 & 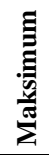 & 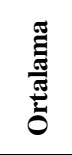 \\
\hline Banka Muhasebesi (Atatürk Üni.) & 14 & 7 & 7 & 0 & 0 & 0 & 0 & 17 & 29 & 19,64 \\
\hline $\begin{array}{c}\text { Banka ve Sigorta Muhasebesi } \\
\text { (Anadolu Üni.) }\end{array}$ & 8 & 6 & 0 & 2 & 0 & 0 & 0 & 26 & 38 & 31,12 \\
\hline $\begin{array}{c}\text { Sigorta Muhasebesi (Atatürk } \\
\text { Üni.) }\end{array}$ & 14 & 9 & 5 & 0 & 0 & 0 & 0 & 16 & 23 & 18,50 \\
\hline TOPLAM & 36 & 22 & 12 & 2 & $\mathbf{0}$ & $\mathbf{0}$ & $\mathbf{0}$ & & & \\
\hline
\end{tabular}

Banka/sigorta muhasebe kategorisinde 2'si Atatürk Üniversitesi'ne, 1'i Anadolu Üniversitesi'ne ait olmak üzere 3 kitap bulunmaktadır. Kitaplardaki toplam bölüm sayısı 36'dır. Unvan açısından en fazla 'Prof.Dr.' unvanlı (22) bölüm yazarı olduğu, bunu sırasıyla 'Doç.Dr.' unvanlı (12) ve 'Dr.Öğr.Üye.' unvanlı (2) bölüm yazarlarının takip ettiği görülmektedir. Üç kitap içerisinde 16 sayfa ile Sigorta Muhasebesi (Atatürk Üni.) kitabındaki 'Gelir Tablosu Hesapları' adlı bölüm en düşük minimum bölüm sayfa sayısına, 38 sayfa ile Banka ve Sigorta Muhasebesi (Anadolu Üni.) kitabındaki 'Kredi Verme İşlemleri ve Muhasebeleştirilmesi' adlı bölüm en yüksek maksimum bölüm sayfa sayısına sahiptir. Banka ve Sigorta Muhasebesi (Anadolu Üni.) kitabı, en yüksek ortalama bölüm sayfa sayısına $(31,12)$ sahiptir. Diğer iki kitabın ortalama bölüm sayfa sayıları birbirine yakındır. 
Tablo 11. Banka/Sigorta Muhasebesi Kategorisindeki Kitapların Kaynak Sayısına, Diline, Türüne ve Yayın Yılına göre Dağılımı

\begin{tabular}{|c|c|c|c|c|c|c|c|c|c|c|c|c|c|c|c|}
\hline \multirow[b]{2}{*}{$\begin{array}{r}\text { Kitap Adı } \\
\text { (Yayınevi) }\end{array}$} & \multirow[b]{2}{*}{ 氙 } & \multicolumn{2}{|c|}{$\begin{array}{c}\text { Kaynak } \\
\text { Dili }\end{array}$} & \multicolumn{7}{|c|}{ Kaynak Türü } & \multicolumn{5}{|c|}{ Kaynak Yayın Yılı } \\
\hline & & 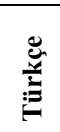 & 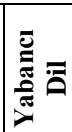 & 馬 & 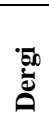 & 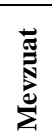 & 离 & : & $\stackrel{\mathbb{N}}{=}$ & 产 & ô: & ஓे & 亏ิे & હેં & 을 ฮิ \\
\hline $\begin{array}{c}\text { Banka } \\
\text { Muhasebesi } \\
\text { (Atatürk Üni.) }\end{array}$ & 109 & 109 & 0 & 94 & 3 & 11 & 0 & 0 & 0 & 1 & 3 & 9 & 13 & 31 & 42 \\
\hline $\begin{array}{c}\text { Banka ve Sigorta } \\
\text { Muhasebesi } \\
\text { (Anadolu Üni.) }\end{array}$ & 45 & 45 & 0 & 44 & 1 & 0 & 0 & 0 & 0 & 0 & 0 & 1 & 8 & 21 & 15 \\
\hline $\begin{array}{c}\text { Sigorta } \\
\text { Muhasebesi } \\
\text { (Atatürk Üni.) }\end{array}$ & 101 & 101 & 0 & 64 & 6 & 19 & 9 & 0 & 2 & 1 & 0 & 1 & 4 & 17 & 55 \\
\hline TOPLAM & 255 & 255 & 0 & 202 & 10 & 30 & 9 & $\mathbf{0}$ & 2 & 2 & 3 & 11 & 25 & 69 & 112 \\
\hline
\end{tabular}

Tablo 11'e göre banka/sigorta muhasebesi kategorisindeki kitaplarda yararlanılan toplam kaynak sayısı 255'tir. Kitap başına 85 (255/3) kaynak düşerken, bölüm başına 7,08 (255/36) kaynak düşmektedir. Kaynak dili açısından kaynakların tamamı (\%100) Türkçedir. Yabancı dilde hiçbir kaynak kullanılmamıştır. Kaynak türü açısından en fazla yararlanılan kaynak; 202 kaynak sayısıyla $(\% 79,21)$ kitap olurken, bunu sırasıyla 30 kaynak sayısıyla $(\% 11,77)$ mevzuat, 10 kaynak sayısıyla $(\% 3,92)$ dergi, 9 kaynak sayısıyla $(\% 3,52)$ internet, 2 'şer kaynak sayısıyla $(\% 0,79)$ tez ve diğer kaynaklar takip etmektedir. Bildiri türünde ise hiçbir kaynak kullanılmamıştır. Kaynakların yayın yılı dağılımına bakıldığında 112 kaynak sayısıyla (\%50,91) en fazla 2010-2020 dönemine ait kaynağın kullanıldı̆̆ı, bunu sirasıyla 69 kaynak sayısıyla (\%31,36) 2000-2009 döneminin, 25 kaynak sayısıyla (\%11,36) 1990-1999 döneminin, 11 kaynak sayısıyla (\%5) 1980-1989 döneminin ve 3 kaynak sayısıyla $(\% 1,37)$ 1980 öncesi dönemin izlediği görülmektedir.

\subsubsection{Muhasebe Bilgi Sistemi/Teknolojisi Kategorisine İlişkin Bulgular}

Muhasebe bilgi sistemi/teknolojisi kategorisinde yer alan kitaplara ait bölüm sayfa sayısı bilgileri verildikten sonra, yararlanılan kaynak sayısına, kaynak diline, kaynak türüne ve kaynak yılına göre kitaplarının dağılımına ait bulgular sunulmuştur.

Tablo 12. Muhasebe Bilgi Sistemi/Tekonolojisi Kategorisindeki Kitapların Bölüm Yazar Unvanları ile Sayfa Sayıları

\begin{tabular}{|c|c|c|c|c|c|c|c|c|c|c|}
\hline \multirow[b]{2}{*}{$\begin{array}{l}\text { Kitap Adı } \\
\text { (Yayınevi) }\end{array}$} & \multirow[b]{2}{*}{$\begin{array}{l}\text { Bölüm } \\
\text { Sayısı }\end{array}$} & \multicolumn{6}{|c|}{ Bölüm Yazar Unvanları } & \multicolumn{3}{|c|}{ Bölüm Sayfa Sayısı } \\
\hline & & 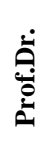 & $\begin{array}{l}\dot{\vec{\Delta}} \\
\text { ¿ू. }\end{array}$ & 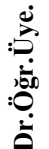 & 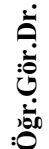 & مَّة: & $\dot{\Delta}$ & 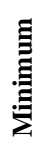 & 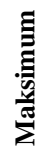 & 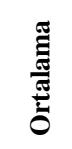 \\
\hline $\begin{array}{l}\text { Muhasebede Bilgi Yönetimi } \\
\text { (Anadolu Üni.) }\end{array}$ & 8 & 7 & 1 & 0 & 0 & 0 & 0 & 16 & 26 & 19,75 \\
\hline $\begin{array}{c}\text { Muhasebe Yazılımları (Anadolu } \\
\text { Üni.) }\end{array}$ & 8 & 2 & 1 & 3 & 0 & 2 & 0 & 20 & 44 & 30,50 \\
\hline $\begin{array}{c}\text { Ön Muhasebe Yazılımları ve } \\
\text { Kullanımı (Anadolu Üni.) }\end{array}$ & 6 & 4 & 2 & 0 & 0 & 0 & 0 & 22 & 34 & 26,83 \\
\hline TOPLAM & 22 & 13 & 4 & 3 & $\mathbf{0}$ & 2 & 0 & & & \\
\hline
\end{tabular}


Muhasebe bilgi sistemi/teknolojisi kategorisinde tümü Anadolu Üniversitesi’ne ait olmak üzere 3 kitap bulunmaktadır. Kitaplardaki toplam bölüm sayısı 22'dir. Unvan açısından en fazla 'Prof. Dr.' unvanlı (13) bölüm yazarı olduğu, bunu sırasılyla 'Doç. Dr.' unvanlı (4), 'Dr. Öğr. Üye.' unvanlı (3) ve 'Öğr.Gör.' unvanlı (2) bölüm yazarlarının takip ettiği görülmektedir. Ụ̈ç kitap içerisinde 16 sayfa ile Muhasebede Bilgi Yönetimi (Anadolu Üni.) kitabındaki 'İşletmelerde Bilgi Sistemleri', 'E-İşletme Sistemleri' ve 'Muhasebe Bilgi Sisteminde Veri Akış Diyagramı' bölümleri en düşük minimum bölüm sayfa sayısına, 44 sayfa ile Muhasebe yazılımları (Anadolu Üni.) kitabındaki 'Satın Alma Yönetimi Modülü’ bölümü en yüksek maksimum bölüm sayfa sayısına sahiptir. Muhasebe Yazılımları (Anadolu Üni.) kitabı, en yüksek ortalama bölüm sayfa sayısına $(30,50)$ sahiptir.

Tablo 13. Muhasebe Bilgi Sistemi/Tekonolojisi Kategorisindeki Kitapların Kaynak Sayısına, Diline, Türüne ve Yayın Yılına göre Dağılımı

\begin{tabular}{|c|c|c|c|c|c|c|c|c|c|c|c|c|c|c|c|}
\hline \multirow[b]{2}{*}{$\begin{array}{l}\text { Kitap Adı } \\
\text { (Yayınevi) }\end{array}$} & \multirow[b]{2}{*}{ 䔍 } & \multicolumn{2}{|c|}{ Kaynak Dili } & \multicolumn{7}{|c|}{ Kaynak Türü } & \multicolumn{5}{|c|}{ Kaynak Yayın Yılı } \\
\hline & & 总 & 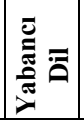 & : & 苞 & & & 音 & $\stackrel{\mathbb{N}}{=}$ & 离 & 局 & 今े & 亏ิे & 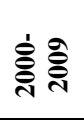 & 을 웛 \\
\hline $\begin{array}{c}\text { Muhasebede } \\
\text { Bilgi } \\
\text { Yönetimi } \\
\text { (Anadolu } \\
\text { Üni.) }\end{array}$ & 105 & 49 & 56 & 72 & 7 & 4 & 7 & 5 & 7 & 3 & 2 & 2 & 15 & 54 & 28 \\
\hline $\begin{array}{c}\text { Muhasebe } \\
\text { Yazılımları } \\
\text { (Anadolu } \\
\text { Üni.) }\end{array}$ & 166 & 75 & 91 & 57 & 65 & 5 & 25 & 7 & 4 & 3 & 0 & 7 & 17 & 96 & 21 \\
\hline $\begin{array}{l}\text { Ön Muhasebe } \\
\text { Yazilımları ve } \\
\text { Kullanımı } \\
\text { (Anadolu } \\
\text { Üni.) }\end{array}$ & 52 & 45 & 7 & 28 & 0 & 4 & 19 & 0 & 1 & 0 & 1 & 0 & 2 & 12 & 20 \\
\hline TOPLAM & 323 & 169 & 154 & 157 & 72 & 13 & 51 & 12 & 12 & 6 & 3 & 9 & 34 & 162 & 69 \\
\hline
\end{tabular}

Tablo 13'e göre muhasebe bilgi sistemi/teknolojisi kategorisindeki kitaplarda yararlanılan toplam kaynak sayısı 323'tür. Kitap başına 107,66 (323/3) kaynak düşerken, bölüm başına 14,68 (323/22) kaynak düşmektedir. 323 kaynağın 169'u (\%52,32) Türkçe olup, 154’ü $(\% 47,68)$ yabancı dildedir. Kaynak türü açısından en fazla yararlanılan kaynak $157(\% 48,60)$ kaynak sayısıyla kitap olurken, bunu sırasıyla 72 kaynak sayısıyla (\%22,30) dergi, 51 kaynak sayısıyla $(\% 15,79)$ internet, 13 kaynak sayısıyla $(\% 4,02)$ mevzuat, 12 'şer kaynak sayısıyla $(\% 3,72)$ bildiri, tez ve 6 kaynak sayısıyla $(\% 1,85)$ diğer kaynaklar takip etmektedir. Kaynakların yayın yılı dağılımı incelendiğinde 162 kaynak sayısıyla $(\% 58,49)$ en fazla 2000 2009 dönemine ait kaynağın kullanıldığı, bunu sirasıyla 69 kaynak sayısıyla $(\% 24,90) 2010$ 2020 döneminin, 34 kaynak sayısıyla (\%12,28) 1990-1999 döneminin, 9 kaynak sayısıyla $(\% 3,25)$ 1980-1989 döneminin ve 3 kaynak sayısıyla $(\% 1,08) 1980$ öncesi dönemin takip ettiği görülmektedir.

\subsubsection{7. Şirketler Muhasebesi Kategorisine İliş̧kin Bulgular}

Şirketler muhasebesi kategorisinde yer alan kitaplara ait bölüm sayfa sayısı bilgileri verildikten sonra, yararlanılan kaynak sayısına, kaynak diline, kaynak türüne ve kaynak yılına göre kitaplarının dağılımına ait bulgular sunulmuştur. 
Tablo 14. Şirketler Muhasebesi Kategorisindeki Kitapların Bölüm Yazar Unvanları ile Sayfa Sayıları

\begin{tabular}{|c|c|c|c|c|c|c|c|c|c|c|}
\hline \multirow[b]{2}{*}{$\begin{array}{l}\text { Kitap Adı } \\
\text { (Yayınevi) }\end{array}$} & \multirow[b]{2}{*}{$\begin{array}{l}\text { Bölüm } \\
\text { Sayısı }\end{array}$} & \multicolumn{6}{|c|}{ Bölüm Yazar Unvanları } & \multicolumn{3}{|c|}{ Bölüm Sayfa Sayısı } \\
\hline & & $\begin{array}{l}\dot{\vec{S}} \\
\dot{\Delta}\end{array}$ & ث̈. & 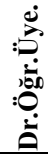 & & مَّْ: & $\ddot{\mathrm{a}}$ & 䒠 & 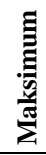 & \\
\hline $\begin{array}{c}\text { Şirketler Muhasebesi (Atatürk } \\
\text { Üni.) }\end{array}$ & 14 & 14 & 0 & 0 & 0 & 0 & 0 & 19 & 28 & 23,00 \\
\hline $\begin{array}{l}\text { Şirketler Muhasebesi } \\
\text { (Anadolu Üni.) }\end{array}$ & 8 & 8 & 0 & 0 & 0 & 0 & 0 & 24 & 32 & 27,25 \\
\hline TOPLAM & 22 & 22 & $\mathbf{0}$ & $\mathbf{0}$ & $\mathbf{0}$ & $\mathbf{0}$ & $\mathbf{0}$ & & & \\
\hline
\end{tabular}

Şirketler muhasebesi kategorisinde 1'i Atatürk Üniversitesine, 1'i Anadolu Üniversitesi'ne ait olmak üzere 2 kitap vardır. Kitaplardaki toplam bölüm sayısı 22'dir. Bölüm yazarlarının tümü 'Prof.Dr.' unvanlıdır (22). İki kitap içerisinde 19 sayfa ile Şirketler Muhasebesi (Atatürk Üni.) kitabındaki 'Halka Açık Olmayan Anonim Şirketlerde Kâr Dağıtımı' adlı bölüm en düşük minimum bölüm sayfa sayısına, 32 sayfa ile Şirketler Muhasebesi (Anadolu Üni.) kitabındaki 'Komandit Şirketler' ile 'Kollektif Şirketler' bölümleri en yüksek maksimum bölüm sayfa sayısına sahiptir. Şirketler Muhasebesi (Anadolu Üni.) kitabının ortalama bölüm sayfa sayısı $(27,25)$, Şirketler Muhasebesi (Atatürk Üni.) kitabının ortalama bölüm sayfa sayısından $(23,00)$ daha fazladir.

Tablo 15. Şirketler Muhasebesi Kategorisindeki Kitapların Kaynak Sayısına, Diline, Türüne ve Yayın Yılına göre Dağılımı

\begin{tabular}{|c|c|c|c|c|c|c|c|c|c|c|c|c|c|c|c|}
\hline \multirow[b]{2}{*}{$\begin{array}{l}\text { Kitap Adı } \\
\text { (Yayınevi) }\end{array}$} & \multirow[b]{2}{*}{ 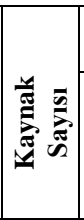 } & \multicolumn{2}{|c|}{$\begin{array}{c}\text { Kaynak } \\
\text { Dili }\end{array}$} & \multicolumn{7}{|c|}{ Kaynak Türü } & \multicolumn{5}{|c|}{ Kaynak Yayın Yılı } \\
\hline & & 总 & 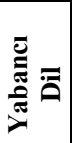 & 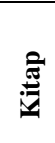 & 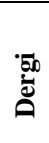 & $\stackrel{\overline{\mathrm{N}}}{\mathrm{E}}$ & . & : & $\stackrel{\Xi}{=}$ & 密 & 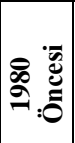 & $\begin{array}{l}\text { के } \\
\frac{1}{5} \\
\stackrel{\circ}{\circ}\end{array}$ & $\frac{\hat{\sigma}}{\hat{\sigma}}$ & 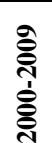 & 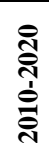 \\
\hline $\begin{array}{c}\text { Şirketler } \\
\text { Muhasebesi } \\
\text { (Atatürk Üni.) }\end{array}$ & 336 & 336 & 0 & 84 & 0 & 154 & 98 & 0 & 0 & 0 & 0 & 0 & 14 & 14 & 56 \\
\hline $\begin{array}{c}\text { Şirketler } \\
\text { Muhasebesi } \\
\text { (Anadolu Üni.) }\end{array}$ & 57 & 57 & 0 & 32 & 0 & 15 & 10 & 0 & 0 & 0 & 0 & 0 & 1 & 14 & 18 \\
\hline TOPLAM & 393 & 393 & 0 & 116 & $\mathbf{0}$ & 169 & 108 & 0 & $\mathbf{0}$ & 0 & 0 & $\mathbf{0}$ & 15 & 28 & 74 \\
\hline
\end{tabular}

Tablo 15'e göre şirketler muhasebesi kategorisindeki kitaplarda yararlanılan toplam kaynak sayıs1 393'tür. Kitap başına 196,50 (393/2) kaynak düşerken, bölüm başına 17,86 (393/22) kaynak düşmektedir. Kaynak dili açısından kaynakların tamamı (\%100) Türkçedir. Kaynak türü açısından en fazla yararlanılan kaynak 169 kaynak sayısıyla $(\% 43,00)$ mevzuat olurken, bunu sırasıyla 116 kaynak sayısıyla $(\% 29,52)$ kitap ve 108 kaynak sayısıyla $(\% 27,48)$ internet takip etmektedir. Dergi, bildiri, tez ve diğer kaynak türünde kaynaklardan faydalanılmamıştır. Kaynakların yayın yılı dağılımına bakıldığında 74 kaynak sayısıyla $(\% 63,25)$ en fazla 2010 2020 dönemine ait kaynağın kullanıldığı, bunu sırasıyla 28 kaynak sayısıyla $(\% 23,93) 2000$ 2009 döneminin, 15 kaynak sayısıyla (\%12,82) da 1990-1999 döneminin izlediği görülmektedir. 1980 öncesi ile 1980-1989 dönemine ait hiçbir kaynaktan faydalanılmamıştır. 


\subsubsection{Dış Ticaret İşlemleri Muhasebesi Kategorisine İlişkin Bulgular}

Dış ticaret işlemleri muhasebesi kategorisinde yer alan kitaplara ait bölüm sayfa sayısı bilgileri verildikten sonra, yararlanılan kaynak sayısına, kaynak diline, kaynak türüne ve kaynak yılına göre kitaplarının dağılımına ait bulgular sunulmuştur.

Tablo 16. Dış Ticaret İşlemleri Kategorisindeki Kitapların Bölüm Yazar Unvanları ile Sayfa Sayıları

\begin{tabular}{|c|c|c|c|c|c|c|c|c|c|c|}
\hline \multirow{2}{*}{$\begin{array}{l}\text { Kitap Adı } \\
\text { (Yayınevi) }\end{array}$} & \multirow{2}{*}{$\begin{array}{l}\text { Bölüm } \\
\text { Sayısı }\end{array}$} & \multicolumn{6}{|c|}{ Bölüm Yazar Unvanları } & \multicolumn{3}{|c|}{ Bölüm Sayfa Sayısı } \\
\hline & & 苛 & 今ே & 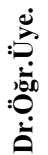 & مَّْ: & 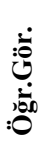 & $\ddot{\Delta}$ & 䒠 & 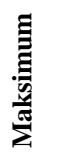 & 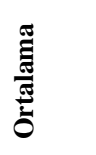 \\
\hline $\begin{array}{l}\text { Dış Ticaret İşlemlerinin } \\
\text { Muhasebeleştirilmesi } \\
\text { (Anadolu Üni.) }\end{array}$ & 8 & 10 & 3 & 0 & 0 & 0 & 0 & 26 & 39 & 30,87 \\
\hline $\begin{array}{l}\text { D1ş Ticaret İslemleri } \\
\text { Muhasebesi (Atatürk Üni.) }\end{array}$ & 14 & 6 & 3 & 5 & 0 & 0 & 0 & 17 & 30 & 21,07 \\
\hline TOPLAM & 22 & 16 & 6 & 5 & $\mathbf{0}$ & $\mathbf{0}$ & $\mathbf{0}$ & & & \\
\hline
\end{tabular}

Dış ticaret işlemleri muhasebesi kategorisinde 1'i Anadolu Üniversitesi'ne, 1'i Atatürk Üniversitesi'ne ait olmak üzere 2 kitap bulunmaktadır. Kitaplardaki toplam bölüm sayısı 22'dir. Unvan açısından en fazla 'Prof.Dr.' unvanlı (16) bölüm yazarı olduğu, bunu sırasıyla 'Doç. Dr.' unvanlı (6) ve 'Dr. Öğr. Üye.' unvanlı (5) bölüm yazarları takip etmektedir. İki kitap içerisinde 17 sayfa ile Dış Ticaret İşlemleri Muhasebesi (Atatürk Üni.) kitabındaki 'Dış Ticaret İşlemlerinde KDV Uygulamaları' ile 'Dış Ticaret İşlemlerinde Transfer Fiyatlaması' bölümleri en düşük minimum bölüm sayfa sayısına, 39 sayfa ile Dış Ticaret İşlemlerinin Muhasebeleștirilmesi (Anadolu Üni.) kitabındaki 'Dış Ticaretin Finansmanı ve Muhasebeleştirilmesi’ adlı bölüm en yüksek maksimum bölüm sayfa sayısına sahiptir. Dış Ticaret İşlemlerinin Muhasebeleştirilmesi (Anadolu Üni.) kitabının ortalama bölüm sayfa sayısı (30,87), Dış Ticaret İşlemleri Muhasebesi (Atatürk Üni.) kitabının ortalama bölüm sayfa sayısından $(21,07)$ daha fazladır.

Tablo 17. Dış Ticaret İşlemleri Muhasebesi Kategorisindeki Kitapların Kaynak Sayısına, Diline,

Türüne ve Yayın Yılına göre Dağılımı

\begin{tabular}{|c|c|c|c|c|c|c|c|c|c|c|c|c|c|c|c|}
\hline \multirow[b]{2}{*}{$\begin{array}{l}\text { Kitap Adı } \\
\text { (Yayınevi) }\end{array}$} & \multirow[b]{2}{*}{ 煎 } & \multicolumn{2}{|c|}{\begin{tabular}{|c|} 
Kaynak \\
Dili
\end{tabular}} & \multicolumn{7}{|c|}{ Kaynak Türü } & \multicolumn{5}{|c|}{ Kaynak Yayın Yılı } \\
\hline & & 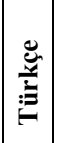 & 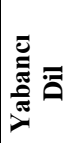 & 产 & 哥 & 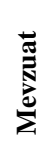 & 氖 & : & $\stackrel{\mathbb{N}}{\Theta}$ & 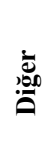 & $\begin{array}{l}\mathscr{\overline { n }} \\
\stackrel{0}{0}\end{array}$ & $\begin{array}{l}\stackrel{\circ}{\circ} \\
\frac{1}{\circ}\end{array}$ & $\frac{\hat{\sigma}}{\frac{\hat{\sigma}}{\sigma}}$ & 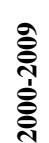 & 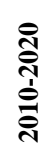 \\
\hline \begin{tabular}{|c|} 
Diş Ticaret \\
İşlemlerinin \\
Muhasebeleştirilmesi \\
(Anadolu Üni.)
\end{tabular} & 90 & 90 & 0 & 37 & 2 & 25 & 23 & 0 & 2 & 1 & 0 & 0 & 6 & 28 & 11 \\
\hline \begin{tabular}{|} 
Diş Ticaret İşlemleri \\
Muhasebesi (Atatürk \\
Üni.)
\end{tabular} & 192 & $\mid 191$ & 1 & 93 & 10 & 16 & 56 & 0 & 4 & 13 & 0 & 4 & 6 & 56 & 81 \\
\hline TOPLAM & 282 & 281 & 1 & 130 & 12 & 41 & 79 & $\mathbf{0}$ & 6 & 14 & $\mathbf{0}$ & 4 & 12 & 84 & 92 \\
\hline
\end{tabular}

Tablo 17'ye göre dış ticaret işlemleri muhasebesi kategorisindeki kitaplarda yararlanılan toplam kaynak sayısı 282'dir. Kitap başına 141 (282/2) kaynak düşerken, bölüm başına 12,81 
(282/22) kaynak düşmektedir. 282 kaynağın 281'i $(\% 99,65)$ Türkçe olup, yalnızca 1'i $(\% 0,35)$ yabancı dildedir. Kaynak türü açısından en fazla yararlanılan kaynak 130 kaynak sayısıyla $(\% 46,10)$ kitap olurken, bunu sirasıyla 79 kaynak sayısıyla $(\% 28,01)$ internet, 41 kaynak sayısıyla $(\% 14,54)$ mevzuat, 14 kaynak sayısıyla $(\% 4,96)$ diğer kaynaklar, 12 kaynak sayısıyla $(\% 4,26)$ dergi ve 6 kaynak sayısıyla $(\% 2,13)$ tez takip etmektedir. Bildiri türünde hiçbir kaynaktan faydalanılmamıştır. Kaynakların yayın yılı dağılımı incelendiğinde 92 kaynak sayısıyla $(\% 47,92)$ en fazla 2010-2020 dönemine ait kaynağın kullanıldığ , bunu sirasıyla 84 kaynak sayısıyla (\%43,75) 2000-2009 döneminin, 12 kaynak sayısıyla (\%6,25) 1990-1999 döneminin ve 4 kaynak sayısıyla $(\% 2,08)$ 1980-1989 döneminin takip ettiği görülmektedir. 1980 öncesi döneme ait hiçbir kaynaktan yararlanılmamıştır.

\subsubsection{9. İnşaat Muhasebesi Kategorisine İlişkin Bulgular}

İnşaat muhasebesi kategorisinde yer alan kitaplara ait bölüm sayfa sayısı bilgileri verildikten sonra, yararlanılan kaynak sayısına, kaynak diline, kaynak türüne ve kaynak yılına göre kitaplarının dağılımına ait bulgular sunulmuştur.

Tablo 18. İnşaat Muhasebesi Kategorisindeki Kitapların Bölüm Yazar Unvanları ile Sayfa

\begin{tabular}{|c|c|c|c|c|c|c|c|c|c|c|}
\hline \multicolumn{11}{|c|}{ Sayıları } \\
\hline \multirow{2}{*}{$\begin{array}{l}\text { Kitap Adı } \\
\text { (Yaymevi) }\end{array}$} & \multirow{2}{*}{$\begin{array}{l}\text { Bölüm } \\
\text { Sayısı }\end{array}$} & \multicolumn{6}{|c|}{ Bölüm Yazar Unvanları } & \multicolumn{3}{|c|}{ Bölüm Sayfa Sayısı } \\
\hline & & 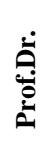 & $\begin{array}{l}\dot{\vec{\ominus}} \\
\dot{\leftrightarrow}\end{array}$ & 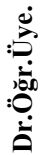 & مَّْ: & مُّن: & $\dot{\vec{\Delta}}$ & 声 & 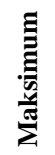 & 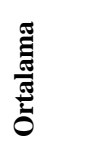 \\
\hline $\begin{array}{l}\text { İnşaat Muhasebesi (Atatürk } \\
\text { Üni.) }\end{array}$ & 14 & 14 & 0 & 0 & 0 & 0 & 0 & 16 & 30 & 20,42 \\
\hline $\begin{array}{l}\text { İnşaat ve Gayrımenkul } \\
\text { Muhasebesi (Anadolu Üni.) }\end{array}$ & 8 & 6 & 1 & 1 & 0 & 0 & 0 & 24 & 38 & 29,00 \\
\hline TOPLAM & 22 & 20 & 1 & 1 & $\mathbf{0}$ & 0 & $\mathbf{0}$ & & & \\
\hline
\end{tabular}

İnşaat muhasebesi kategorisinde 1'i Atatürk Üniversitesi'ne, 1'i Anadolu Üniversitesi'ne ait olmak üzere 2 kitap vardır. Kitaplardaki toplam bölüm sayısı 22'dir. Unvan açısından en fazla 'Prof.Dr.' unvanlı (20) bölüm yazarı olduğu, bunu sırasıyla 'Doç.Dr.' unvanlı (1) ve 'Dr.Öğr.Üye' unvanlı (1) bölüm yazarlarının takip ettiği görülmektedir. İki kitap içerisinde 16 sayfa ile İnşaat Muhasebesi (Atatürk Üni.) kitabındaki ‘Özel (YAP-SAT) İnşaat İşletmelerinde Taşeron ve Diğer Direkt Giderlerin Muhasebeleştirilmesi' ile 'Özel (YAP-SAT) ve Yıllara Yaygın İnşaat Faaliyetinde Genel Üretim Giderlerinin Dağıtımı ve Muhasebeleştirilmesi’ bölümleri en düşük minimum bölüm sayfa sayısına, 38 sayfa ile İnşaat ve Gayrımenkul Muhasebesi (Anadolu Üni.) kitabındaki 'Yıllara Yaygın İnşaat ve Onarım İşlerinde Maliyet Muhasebesi' adlı bölüm en yüksek maksimum bölüm sayfa sayısına sahiptir. İnşaat ve Gayrımenkul Muhasebesi (Anadolu Üni.) kitabının ortalama bölüm sayfa sayısı (29,00), İnşaat Muhasebesi (Atatürk Üni.) kitabının ortalama bölüm sayfa sayısından $(20,42)$ daha fazladır. 
Tablo 19. İnşaat Muhasebesi Kategorisindeki Kitapların Kaynak Sayısına, Diline, Türüne ve Yayın Yılına göre Dağılımı

\begin{tabular}{|c|c|c|c|c|c|c|c|c|c|c|c|c|c|c|c|}
\hline \multirow[b]{2}{*}{$\begin{array}{l}\text { Kitap Adı } \\
\text { (Yayınevi) }\end{array}$} & \multirow[b]{2}{*}{ 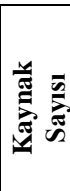 } & \multicolumn{2}{|c|}{ Kaynak Dili } & \multicolumn{7}{|c|}{ Kaynak Türü } & \multicolumn{5}{|c|}{ Kaynak Yayın Yılı } \\
\hline & & : & 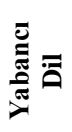 & ज्ञ & 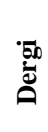 & 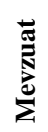 & & 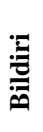 & $\stackrel{\mathbb{N}}{=}$ & 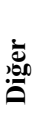 & 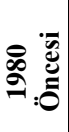 & 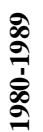 & $\begin{array}{l}\text { बे } \\
\text { ڤे }\end{array}$ & 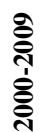 & 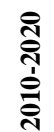 \\
\hline $\begin{array}{c}\text { İnşaat Muhasebesi } \\
\text { (Atatürk Üni.) }\end{array}$ & 199 & 199 & 0 & 109 & 16 & 27 & 13 & 0 & 30 & 4 & 0 & 2 & 4 & 53 & 105 \\
\hline $\begin{array}{c}\text { İnşaat ve } \\
\text { Gayrımenkul } \\
\text { Muhasebesi } \\
\text { (Anadolu Üni.) }\end{array}$ & 138 & 138 & 0 & 44 & 20 & 44 & 13 & 8 & 9 & 0 & 0 & 2 & 5 & 46 & 40 \\
\hline TOPLAM & $\mathbf{3 3 7}$ & 337 & $\mathbf{0}$ & 153 & 36 & 71 & 26 & 8 & 39 & 4 & 0 & 4 & 9 & 99 & 145 \\
\hline
\end{tabular}

Tablo 19'a göre inşaat muhasebesi kategorisindeki kitaplarda yararlanılan toplam kaynak sayısı 337'dir. Kitap başına 168,50 (337/2) kaynak düşerken, bölüm başına 15,31 (337/22) kaynak düşmektedir. Kaynak dili açısından kaynakların tümü (\%100) Türkçedir. Kaynak türü açısından en fazla yararlanılan kaynak 153 kaynak sayısıyla $(\% 45,40)$ kitap olurken, bunu sirasıyla 71 kaynak sayısıyla (\%21,07) mevzuat, 39 kaynak sayısıyla $(\% 11,57)$ tez, 36 kaynak sayısıyla $(\% 10,68)$ dergi, 26 kaynak sayısıyla $(\% 7,72)$ internet, 8 kaynak sayısıyla $(\% 2,37)$ bildiri ve 4 kaynak sayısıyla $(\% 1,19)$ diğer kaynaklar takip etmektedir. Kaynakların yayın yılı dağılımına bakıldığında 145 kaynak sayısıyla $(\% 56,42)$ en fazla 2010-2020 dönemine ait kaynağın kullanıldığı, bunu sırasıyla 99 kaynak sayısıyla $(\% 38,52)$ 2000-2009 döneminin, 9 kaynak sayısıyla $(\% 3,50)$ 1990-1999 döneminin ve 4 kaynak sayısıyla $(\% 1,56)$ 1980-1989 döneminin izlediği anlaşılmaktadır. 1980 öncesi döneme ait hiçbir kaynaktan faydalanılmamıştır.

\subsubsection{Muhasebe Uygulamaları Kategorisine İlişkin Bulgular}

Muhasebe uygulamaları kategorisinde yer alan kitaplara ait bölüm sayfa sayısı bilgileri verildikten sonra, yararlanılan kaynak sayısına, kaynak diline, kaynak türüne ve kaynak yılına göre kitaplarının dağılımına ait bulgular sunulmuştur.

Tablo 20. Muhasebe Uygulamaları Kategorisindeki Kitapların Bölüm Yazar Unvanları ile Sayfa Sayıları

\begin{tabular}{|c|c|c|c|c|c|c|c|c|c|c|}
\hline \multirow{2}{*}{$\begin{array}{l}\text { Kitap Adı } \\
\text { (Yayınevi) }\end{array}$} & \multirow{2}{*}{$\begin{array}{l}\text { Bölüm } \\
\text { Sayısı }\end{array}$} & \multicolumn{6}{|c|}{ Bölüm Yazar Unvanları } & \multicolumn{3}{|c|}{ Bölüm Sayfa Sayısı } \\
\hline & & 官 & 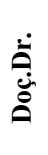 & 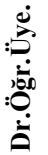 & 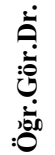 & 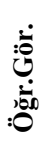 & $\dot{\vec{\Delta}}$ & 声 & 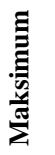 & 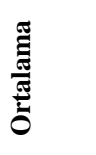 \\
\hline $\begin{array}{ll}\text { Muhasebe } & \text { Uygulamaları } \\
\text { (Anadolu Üni.) }\end{array}$ & 8 & 8 & 0 & 0 & 0 & 0 & 0 & 14 & 34 & 24,87 \\
\hline $\begin{array}{lr}\text { Konaklama } & \text { İşletmelerinde } \\
\text { Muhasebe } & \text { Uygulamaları } \\
\text { (Anadolu Üni.) } & \end{array}$ & 8 & 0 & 4 & 4 & 0 & 0 & 0 & 24 & 34 & 29,25 \\
\hline TOPLAM & 16 & 8 & 4 & 4 & $\mathbf{0}$ & $\mathbf{0}$ & $\mathbf{0}$ & & & \\
\hline
\end{tabular}

Muhasebe uygulamaları kategorisinde tümü Anadolu Üniversitesi'ne ait olmak üzere 2 kitap bulunmaktadır. Kitaplardaki toplam bölüm sayısı 16'dır. Unvan açısından en fazla 'Prof. Dr.' unvanlı (8) bölüm yazarı olduğu, bunu sırasıyla 'Doç. Dr.' unvanlı (4) ve 'Dr. Öğr. Üye.' unvanlı (4) bölüm yazarlarının izlediği görülmektedir. İki kitap içerisinde 14 sayfa ile 1694 
Muhasebe Uygulamaları (Anadolu Üni.) kitabındaki 'Dönem Sonu İşlemleri' adlı bölüm en düşük minimum bölüm sayfa sayısına, 34 sayfa ile Muhasebe Uygulamaları (Anadolu Üni.) kitabındaki 'Ticaret Şirketlerinde Kuruluş İşlemleri ve Sermaye Değişiklikleri' ile Konaklama İşletmelerinde Muhasebe Uygulamaları (Anadolu Üni.) kitabındaki 'Bütçeleme ve Bütçe Sapma Analizleri' bölümleri en yüksek maksimum bölüm sayfa sayısına sahiptir. Konaklama İşletmelerinde Muhasebe Uygulamaları (Anadolu Üni.) kitabının ortalama bölüm sayfa sayısı $(29,25)$, Muhasebe Uygulamaları (Anadolu Üni.) kitabının ortalama bölüm sayfa sayısından $(24,87)$ daha fazladir.

Tablo 21. Muhasebe Uygulamaları Kategorisindeki Kitapların Kaynak Sayısına, Diline, Türüne ve Yayın Yılına göre Dağılımı

\begin{tabular}{|c|c|c|c|c|c|c|c|c|c|c|c|c|c|c|c|}
\hline \multirow[b]{2}{*}{$\begin{array}{l}\text { Kitap Adı } \\
\text { (Yayınevi) }\end{array}$} & \multirow[b]{2}{*}{ 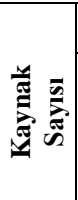 } & \multicolumn{2}{|c|}{ Kaynak Dili } & \multicolumn{7}{|c|}{ Kaynak Türü } & \multicolumn{5}{|c|}{ Kaynak Yayın Yılı } \\
\hline & & 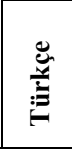 & 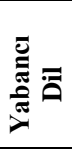 & 衰 & 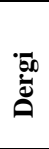 & 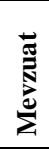 & 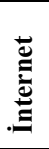 & : & 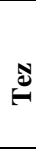 & 离 & 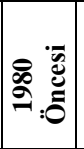 & $\frac{\mathscr{2}}{\grave{\circ}}$ & $\frac{\sigma}{\hat{\sigma}}$ & 言 & 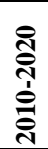 \\
\hline $\begin{array}{c}\text { Muhasebe } \\
\text { Uygulamaları } \\
\text { (Anadolu Üni.) }\end{array}$ & 40 & 40 & 0 & 29 & 0 & 9 & 2 & 0 & 0 & 0 & 0 & 0 & 0 & 6 & 18 \\
\hline $\begin{array}{c}\text { Konaklama } \\
\text { İşletmelerinde } \\
\text { Muhasebe } \\
\text { Uygulamaları } \\
\text { (Anadolu Üni.) }\end{array}$ & 80 & 73 & 7 & 61 & 2 & 10 & 3 & 3 & 1 & 0 & 3 & 0 & 10 & 33 & 17 \\
\hline TOPLAM & 120 & 113 & 7 & 90 & 2 & 19 & 5 & 3 & 1 & $\mathbf{0}$ & 3 & $\mathbf{0}$ & 10 & 39 & 35 \\
\hline
\end{tabular}

Tablo 21'e göre muhasebe uygulamaları kategorisindeki kitaplarda yararlanın toplam kaynak sayısı 120'dir. Kitap başına 60,00 (120/2) kaynak düşerken, bölüm başına 7,50 (120/16) kaynak düşmektedir. 120 kaynağın 113 'ü $(\% 94,17)$ Türkçe olup, yalnızca 7'si $(\% 5,83)$ yabancı dildedir. Kaynak türü açısından en fazla yararlanılan kaynak 90 kaynak sayısıyla (\%75) kitap olurken, bunu sirasiyla 19 kaynak sayısıyla $(\% 15,83)$ mevzuat, 5 kaynak sayısıyla $(\% 4,17)$ internet, 3 kaynak sayısıyla $(\% 2,5)$ bildiri, 2 kaynak sayısıyla $(\% 1,67)$ dergi ve 1 kaynak sayısıyla $(\% 0,83)$ tez izlemektedir. Diğer kaynak türünde hiçbir kaynaktan yararlanılmamıştır. Kaynakların yayın yılı dağılımına bakıldığında 39 kaynak sayısıyla $(\% 44,83)$ en fazla 2000 2009 dönemine ait kaynağın kullanıldığı, bunu sırasıyla 35 kaynak sayısıyla (\%40,23) 20102020 döneminin, 10 kaynak sayısıyla $(\% 11,49)$ 1990-1999 döneminin ve 3 kaynak sayısıyla $(\% 3,45) 1980$ öncesi dönemin takip ettiği görülmektedir. 1980-1989 dönemine ait hiçbir kaynak kullanılmamıştır.

\subsubsection{Muhasebe ve Hukuk Kategorisine İlişkin Bulgular}

Muhasebe ve hukuk kategorisinde yer alan kitaba ait bölüm sayfa sayısı bilgileri verildikten sonra, yararlanılan kaynak sayısına, kaynak diline, kaynak türüne ve kaynak yılına göre kitabın dağılımına ait bulgular sunulmuştur. 
Tablo 22. Muhasebe ve Hukuk Kategorisindeki Kitabın Bölüm Yazar Unvanları ile Sayfa Sayıları

\begin{tabular}{|c|c|c|c|c|c|c|c|c|c|c|}
\hline \multirow[b]{2}{*}{$\begin{array}{l}\text { Kitap Adı } \\
\text { (Yayınevi) }\end{array}$} & \multirow[b]{2}{*}{$\begin{array}{l}\text { Bölüm } \\
\text { Sayısı }\end{array}$} & \multicolumn{6}{|c|}{ Bölüm Yazar Unvanları } & \multicolumn{3}{|c|}{ Bölüm Sayfa Sayısı } \\
\hline & & 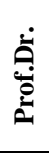 & $\begin{array}{l}\dot{\vec{\Delta}} \\
\dot{\Delta}\end{array}$ & 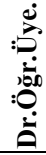 & 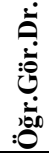 & 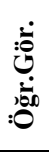 & $\dot{\vec{\Delta}}$ & 䒠 & 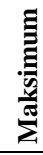 & 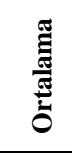 \\
\hline Muhasebe ve Hukuk (Anadolu Üni.) & 8 & 6 & 0 & 2 & 0 & 0 & 0 & 16 & 40 & 24,00 \\
\hline
\end{tabular}

Muhasebe ve hukuk kategorisinde yalnızca Anadolu Üniversitesi’ne ait 1 kitap bulunmaktadır. Bu kitapta toplam 8 bölüm vardır. Unvan açısından en fazla 'Prof. Dr.' unvanlı (6) bölüm yazarı olduğu, bunu 'Dr. Öğr. Üye' unvanının (2) takip ettiği görülmektedir. 'Sosyal Düzen Kuralları ve Hukuk' ile 'Mali Tablolar (Finansal Tablolar)' bölümleri minimum bölüm sayfa sayısına (16), 'Defterler ve Belgeler' adlı bölüm maksimum bölüm sayfa sayınsa (40) sahiptir. Ortalama bölüm sayfa sayısı ise 24,00'dır.

Tablo 23. Muhasebe ve Hukuk Kategorisindeki Kitabın Kaynak Sayısına, Diline, Türüne ve Yayın Yılına göre Dağılımı

\begin{tabular}{|c|c|c|c|c|c|c|c|c|c|c|c|c|c|c|c|}
\hline \multirow[b]{2}{*}{$\begin{array}{l}\text { Kitap Adı } \\
\text { (Yayınevi) }\end{array}$} & \multirow[b]{2}{*}{ 施 } & \multicolumn{2}{|c|}{ Kaynak Dili } & \multicolumn{7}{|c|}{ Kaynak Türü } & \multicolumn{5}{|c|}{ Kaynak Yayın Yılı } \\
\hline & & : & 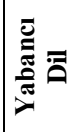 & 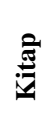 & 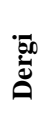 & 㺼 & & 焉 & $\stackrel{\Phi}{~}$ & 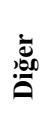 & 离 & ڤે & 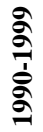 & 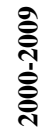 & 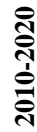 \\
\hline $\begin{array}{c}\text { Muhasebe ve } \\
\text { Hukuk (Anadolu } \\
\text { Üni.) }\end{array}$ & 91 & 88 & 3 & 49 & 2 & 7 & 30 & 0 & 1 & 2 & 1 & 2 & 6 & 23 & 51 \\
\hline
\end{tabular}

Tablo 23'e göre Muhasebe ve Hukuk (Anadolu Üni.) kitabındaki toplam kaynak sayıs1 91'dir. Bölüm başına 11,37 (91/8) kaynak düşmektedir. 91 kaynağın 88’i $(\% 96,70)$ Türkçe olup, yalnızca 3'ü $(\% 3,30)$ yabancı dildedir. Kaynak türü açısından en fazla yararlanılan kaynak 49 kaynak sayısıyla $(\% 53,85)$ kitap olurken, bunu sirasıyla 30 kaynak sayısıla $(\% 32,97)$ internet, 7 kaynak sayısıyla $(\% 7,69)$ mevzuat, 2 'şer kaynak sayısıyla $(\% 2,20)$ dergi ile diğer kaynaklar ve 1 kaynak sayısıyla $(\% 1,09)$ tez izlemektedir. Bildiri türünde hiçbir kaynaktan yararlanılmamıştır. Kaynak yayın yılı dağılımı incelendiğinde 51 kaynak sayısıyla $(\% 61,45)$ en fazla 2010-2020 dönemine ait kaynağın kullanıldığı, bunu sırasıyla 23 kaynak sayısıyla (\%27,71) 2000-2009 döneminin, 6 kaynak sayısıyla (\%7,23) 1990-1999 döneminin, 2 kaynak sayısıyla $(\% 2,41)$ 1980-1989 döneminin ve 1 kaynak sayısıyla $(\% 1,20) 1980$ öncesi dönemin takip ettiği görülmektedir.

\subsubsection{Mali Tablolar Analizi/Finansal Analiz Kategorisine İlişkin Bulgular}

Mali tablolar analizi/finansal analiz kategorisinde yer alan kitaplara ait bölüm sayfa sayısı bilgileri verildikten sonra, yararlanılan kaynak sayısına, kaynak diline, kaynak türüne ve kaynak yılına göre kitabın dağılımına ait bulgular sunulmuştur. 
Tablo 24. Mali Tablolar Analizi/Finansal Analiz Kategorisindeki Kitapların Bölüm Yazar Unvanları ile Sayfa Sayıları

\begin{tabular}{|c|c|c|c|c|c|c|c|c|c|c|}
\hline \multirow{2}{*}{$\begin{array}{l}\text { Kitap Adı } \\
\text { (Yayınevi) }\end{array}$} & \multirow{2}{*}{$\begin{array}{l}\text { Bölüm } \\
\text { Sayısı }\end{array}$} & \multicolumn{6}{|c|}{ Bölüm Yazar Unvanları } & \multicolumn{3}{|c|}{ Bölüm Sayfa Sayısı } \\
\hline & & & $\begin{array}{l}\dot{\vec{\theta}} \\
\stackrel{\dot{0}}{\circ}\end{array}$ & 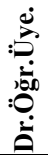 & 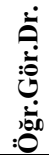 & مَّْ: & $\dot{\vec{\Delta}}$ & 䒠 & 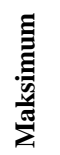 & 营 \\
\hline $\begin{array}{l}\text { Finansal Tablolar } \\
\text { (Anadolu Üni.) }\end{array}$ & 8 & 6 & 1 & 1 & 0 & 0 & 0 & 20 & 34 & 26,12 \\
\hline $\begin{array}{l}\text { Mali Tablolar Analizi (Atatürk } \\
\text { Üni.) }\end{array}$ & 14 & 9 & 3 & 2 & 0 & 0 & 0 & 17 & 27 & 20,71 \\
\hline Mali Analiz (Anadolu Üni.) & 8 & 5 & 1 & 2 & 0 & 0 & 0 & 14 & 28 & 21,75 \\
\hline $\begin{array}{l}\text { Muhasebe Denetimi ve Mali } \\
\text { Analiz (Anadolu Üni.) }\end{array}$ & 4 & 0 & 4 & 0 & 0 & 0 & 0 & 14 & 20 & 16,50 \\
\hline TOPLAM & 34 & 20 & 9 & 5 & $\mathbf{0}$ & $\mathbf{0}$ & $\mathbf{0}$ & & & \\
\hline
\end{tabular}

Mali tablolar analizi/finansal analiz kategorisinde 3'ü Anadolu Üniversitesi'ne 1'i Atatürk Üniversitesi'ne ait olmak üzere 4 kitap bulunmaktadır. Kitaplardaki toplam bölüm sayısı 34'tür. Unvan açısından en fazla 'Prof. Dr.' unvanlı (20) bölüm yazarı olduğu, bunu sırasıyla 'Doç. Dr.' unvanlı (9) ve 'Dr. Öğr. Üye.' unvanlı (5) bölüm yazarlarının takip ettiği görülmektedir. Dört kitap içerisinde 14 sayfa ile Mali Analiz (Anadolu Üni.) kitabındaki 'Likidite ve Kısa Dönemli Borç Ödeme Gücü' adlı bölüm ve Muhasebe Denetimi ve Mali Analiz (Anadolu Üni.) kitabındaki 'Trend Analiz Tekniği' adlı bölüm en düşük minimum bölüm sayfa sayısına, 34 sayfa ile Finansal Tablolar Analizi (Anadolu Üni.) kitabındaki 'Finansal Analiz Teknikleri' adlı bölüm en yüksek maksimum bölüm sayfa sayısına sahiptir. Finansal Tablolar Analizi (Anadolu Üni.) kitabı, en yüksek ortalama bölüm sayfa sayısına $(26,12)$ sahiptir.

Tablo 25. Mali Tablolar Analizi/Finansal Analiz Kategorisindeki Kitapların Kaynak Sayısına, Diline, Türüne ve Yayın Yılına göre Dağılımı

\begin{tabular}{|c|c|c|c|c|c|c|c|c|c|c|c|c|c|c|c|}
\hline \multirow[b]{2}{*}{$\begin{array}{l}\text { Kitap Adı } \\
\text { (Yayınevi) }\end{array}$} & \multirow[b]{2}{*}{ 莺 } & \multicolumn{2}{|c|}{ Kaynak Dil } & \multicolumn{7}{|c|}{ Kaynak Türü } & \multicolumn{5}{|c|}{ Kaynak Yayın Yılı } \\
\hline & & 总 & 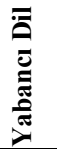 & 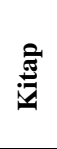 & 苞 & 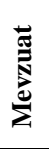 & & : & $\stackrel{\Xi}{=}$ & 离 & : & $\begin{array}{l}\stackrel{\circ}{\circ} \\
\text { ळे }\end{array}$ & 亏ิे & 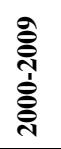 & 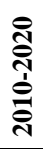 \\
\hline $\begin{array}{c}\text { Finansal Tablolar } \\
\text { Analizi (Anadolu } \\
\text { Üni.) } \\
\end{array}$ & 75 & 51 & 24 & 54 & 14 & 1 & 5 & 0 & 1 & 0 & 1 & 8 & 9 & 32 & 23 \\
\hline $\begin{array}{c}\text { Mali Tablolar } \\
\text { Analizi (Atatürk } \\
\text { Üni.) }\end{array}$ & 102 & 90 & 12 & 67 & 18 & 5 & 8 & 1 & 2 & 1 & 0 & 5 & 9 & 27 & 53 \\
\hline $\begin{array}{c}\text { Mali Analiz } \\
\text { (Anadolu Üni.) }\end{array}$ & 54 & 38 & 16 & 46 & 3 & 0 & 5 & 0 & 0 & 0 & 0 & 3 & 7 & 27 & 12 \\
\hline $\begin{array}{c}\text { Muhasebe } \\
\text { Denetimi ve Mali } \\
\text { Analiz (Anadolu } \\
\text { Üni.) } \\
\end{array}$ & 29 & 23 & 6 & 29 & 0 & 0 & 0 & 0 & 0 & 0 & 0 & 0 & 2 & 17 & 10 \\
\hline TOPLAM & 260 & 202 & 58 & 196 & 35 & 6 & 18 & 1 & 3 & 1 & 1 & 16 & 27 & 103 & 98 \\
\hline
\end{tabular}

$\S$ Analizde mali tablolar analizi/finansal analiz ile ilgili olan bölümler dikkate alınmıştır. 
Tablo 25'e göre mali tablolar analizi/finansal analiz kategorisindeki kitaplarda yararlanılan toplam kaynak sayısı 260’tır. Kitap başına 65 (260/4) kaynak düşerken, bölüm başına 7,64 (260/34) kaynak düşmektedir. 260 kaynağın 202'si $(\% 77,70)$ Türkçe olup, 58'i $(\% 22,30)$ yabancı dildedir. Kaynak türü açısından en fazla yararlanılan kaynak 196 kaynak sayısıyla $(\% 75,39)$ kitap olurken, bunu sırasıyla 35 kaynak sayısıyla $(\% 13,47)$ dergi, 18 kaynak sayısıyla $(\% 6,93)$ internet, 6 kaynak sayısıyla $(\% 2,30)$ mevzuat, 3 kaynak sayısıla $(\% 1,15)$ tez, 1 'er kaynak sayısıyla $(\% 0,38)$ bildiri ve diğer kaynaklar izlemektedir. Kaynakların yayın yılı dağılımına bakıldığında 103 kaynak sayısıyla (\%42,04) en fazla 2000-2009 dönemine ait kaynağın kullanıldığı, bunu sırasıyla 98 kaynak sayısıyla (\%40) 2010-2020 döneminin, 27 kaynak sayısıyla (\%11,02) 1990-1999 döneminin, 16 kaynak sayısıyla (\%6,53) 1980-1989 döneminin ve 1 kaynak sayısıyla $(\% 0,41) 1980$ öncesi dönemin takip ettiği görülmektedir.

\section{SONUÇ VE ÖNERILER}

Tamamlayıcı ve alternatif bir eğitim türü olarak değerlendirilebilecek uzaktan eğitim Covid-19 pandemisinin ortaya çıkmasından sonra önemini artırmış, pandemi sona erdikten sonra da önemini koruyacağı düşünülmektedir. Uzaktan eğitimin kalitesini belirleyen önemli unsurlardan biri de uzaktan eğitim de sunulan ders içerikleri ile ders materyallerinin kalitesidir.

YÖK dersleri platformu, ülkemizde yüksek öğretim düzeyinde uzaktan eğitim ders içerikleri barındıran önemi bir platformdur. Bu çalışmada bu platformda açık erişime sunulan 41 muhasebe kitabı bibliyometrik analizle incelenmeye çalışılmıştır.

Anadolu Üniversitesi'nin, Atatürk Üniversitesi'nin 2 katından daha fazla bir yayına sahip olduğu görülmektedir. Bu beklenen bir durumdur çünkü Anadolu Üniversitesi, uzaktan eğitimi ülkemizde çağdaş anlamda yüksek öğretim düzeyinde uygulayan ilk üniversitedir. Ancak çeşitliliğin artması bakımından diğer üniversitelerin de bu platforma katkı sunması beklenmektedir.

Yayın yılı incelendiğinde 2017 yılından itibaren daha fazla yayının olduğu göze çarpmaktadır. $\mathrm{Bu}$ da, yayınların güncel olduğu şeklinde yorumlanabilir. Editörlerin ağırlıklı kısmının 'Prof. Dr.' unvanlı olduğu görülmektedir. Bu çerçevede daha dengeli bir unvan dağılımın sağlanması açısından ileride hazırlanacak kitaplarda daha fazla sayıda 'Doç. Dr.' ve 'Dr. Öğr. Üye' unvanlı akademisyenin editörlük yapması tavsiye edilebilir.

Atatürk Üniversitesi'ne ait yayınların bölüm sayısı standart olup, 14 bölümdür. Anadolu Üniversitesi'nin yayınlarında ise 3 yayın hariç bölüm sayısı 8'dir. Anadolu Üniversitesi'nin yayınlarında içeriğe uygun olarak bölüm sayısı açısından standart hale getirilebilir.

En fazla sayıda yayının açık erişime sunulduğu fakülte, İktisadi ve İdari Bilimler Fakültesi (İ̈BF), meslek yüksekokulu ise Sosyal Bilimler MYO'dur. İİBF ve Sosyal Bilimler MYO altında çok fazla bölüm ve program bulunduğundan bu beklenen bir durumdur.

En fazla sayıda yayını barındıran kategori yönetim/maliyet muhasebesi kategorisi iken, en az sayıda yayını barındıran kategori muhasebe ve hukuktur. Muhasebe ve hukuk kategorisinde muhasebenin başta ticaret hukuku, vergi hukuku gibi çeşitli hukuk dalları ilişkisini ortaya koyan daha fazla sayıda yayın sunulabilir.

İstisnasız olarak tüm muhasebe kategorilerinde 'Prof. Dr.' unvanlı bölüm yazarı sayısı, diğer unvanlardan daha fazladır. 'Öğr. Gör. Dr.', 'Öğr. Gör.' ve 'Dr' unvanlı bölüm yazarı ise az sayıda bulunmaktadır. 'Öğr. Gör. Dr.' unvanlı bölüm yazarları sadece dönem sonu muhasebesi 
ile yönetim/maliyet muhasebesi kategorisinde, 'Öğr. Gör.' unvanlı bölüm yazarları sadece muhasebe bilgi sistemi/teknolojisi kategorisinde bulunurken, 'Dr.' Unvanlı bölüm yazarı yalnızca dönem sonu muhasebe kategorisinde yer almaktadır. Genel muhasebe, şirketler muhasebesi ile muhasebe ve hukuk kategorilerinde hiç 'Doç. Dr.' unvanlı bölüm yazarı bulunmazken, genel muhasebe ile şirketler muhasebesi kategorisinde 'Dr. Öğr. Üye.' unvanlı bölüm yazarı bulunmamaktadır. Daha dengeli bir unvan dağılımını sağlamak adına ileride hazırlanacak yayınlarda başta ‘Öğr. Gör. Dr.', 'Öğr. Gör.' unvanlı olmak üzere 'Doç. Dr.' ve 'Dr. Öğr. Üye.' unvanlı akademisyenlere daha fazla bölüm yazarlığı sunulabilir.

Muhasebe bilgi sistemi/teknolojisi kategorisi hariç diğer tüm kategorilerde Türkçe kaynakların ağırlığının yabancı dildeki kaynaklara göre daha fazla olduğu görülmektedir. Muhasebe bilgi sistemi/teknolojisi kategorisinde ise yüzde olarak hemen hemen birbirine eşit oranda Türkçe ve yabancı dilde kaynak kullanılmıştır. Banka/sigorta muhasebesi, şirketler muhasebesi ile inşaat muhasebesi kategorilerinde ise hiçbir yabancı dilde kaynak kullanılmamış, dış ticaret işlemleri muhasebesi kategorisinde ise yalnızca bir adet yabancı dilde kaynak kullanılmıştır. Uluslararası muhasebe gündemini takip etmek, uluslararası muhasebe ile gelişmeleri yansıtmak ve muhasebeyle ilgili uluslararası alandaki güncelliği yakalamak için başta banka/sigorta muhasebesi, şirketler muhasebesi, inşaat muhasebesi, dış ticaret işlemleri muhasebesi kategorileri olmak üzere muhasebe bilgi sistemi/teknolojisi kategorisi hariç diğer tüm kategorilerde hazırlanacak kitaplarda yabancı dilde kaynak kullanımı artırılmalıdır.

Şirketler muhasebesi kategorisi hariç diğer tüm kategorilerde kitap, diğer kaynak türleri arasında en çok başvurulan kaynak olmuştur. Şirketler muhasebesi kategorisinde ise en çok başvurulan kaynak, mevzuat olmuştur. Şirketler muhasebesindeki konular şirket türleri ve buna bağlı olarak ticaret hukuku ile diğer kanunlarla ilgili olması nedeniyle mevzuat türünde kaynaklara daha fazla başvurulması doğaldır.

Kategori ayrımı olmaksızın tüm muhasebe kitaplarında yararlanılan kaynakların tamamı en çok başvurulandan en az başvurulana doğru sıralandığında, birinci sırada kitap, ikinci sırada dergi, üçüncü sırada internet, dördüncü sırada mevzuat, beşinci sırada tez, altıncı sırada diğer kaynaklar ve son sırada bildiri yer almaktadır.

1980 öncesi, 1980-1989 ile 1990-1999 dönemlerinin her birine kıyasla tüm muhasebe kategorilerinde 2000-2009 ile 2010-2020 dönemlerinin her birine ait daha fazla kaynak kullanılmıştır. Kategori ayrımı olmaksızın tüm muhasebe kitaplarında yararlanılan kaynakların tamamına ait yayın yılı dağılımı incelendiğinde, en çok 2000-2009 dönemine ait kaynağın kullanıldığı, bunu 2010-2020 döneminin izlediği, en az ise 1980 öncesi döneme ait kaynaktan faydalanıldığı görülmüştür. Genel olarak güncel kaynakların daha fazla kullanıldığı ifade edilebilir.

\section{KAYNAKÇA}

AKPINAR, S., \& YILDIZ, Ş. (2020). "Muhasebe Bilim Dalında Özgün Eserler: Türk Yazını İncelemesi”. BAİBÜ Sosyal Bilimler Enstitüsü Dergisi, 20(1): 97-120.

AKYÜZ, F., \& YEŞİL, T. (2019). "Reviewed of National and International Printed Books Written in Management Accounting”. Muhasebe ve Finansman Dergisi, Ağustos 2019 (Özel Say1): 101-114. 
APAK, S., EROL, M., \& ÖZTÜRK, S. (2016). "Muhasebe ve Finans Tarihi Araştırmaları Dergisinde Yayınlanan Makalelerin Bibliyometrik Analizi”. Muhasebe ve Finans Tarihi Araştırmaları Dergisi, (11): 111-124.

AYDEMIR, M. (2018). Uzaktan Eğitim Program, Ders ve Materyal Tasarımı. Eğitim Yayınevi, Konya.

BALL, R. (2018). An Introduction to Bibliometrics New Development and Trends. Chandos Publishing, Cambridge, Kidlington.

DOĞAN, M., \& ERTUGAY, E. (2019). "Genel Muhasebe Ders Kitaplarının Okunabilirlik Düzeyleri Üzerine Bir Araştırma”. Muhasebe Bilim Dünyası Dergisi, 21(4): 863-878.

GÜNDÜZ, M. (2018). "Türkiye'de 2014-2016 Yılları Arasında Akademik Dergilerde Muhasebe Alanında Yayınlanan Makalelerin Bibliyometrik Analizi”. Muhasebe Bilim Dünyası Dergisi, 20(1): 236-257.

HASSAN, M. K., ALSHATER, M. M., MUMU, J. R., SAREA, A. M., \& AZAD, M. A. (2021). "Bibliometric Analysis of the Journal of Islamic Accounting and Business Research: Ten Years Review". COLLNET Journal of Scientometrics and Information Management, 15(1), 63-88.

HOTAMIȘLI, M., \& EREM, I. (2014). "Muhasebe ve Finansman Dergisi'nde Yayınlanan Makalelerin Bibliyometrik Analizi". Muhasebe ve Finansman Dergisi, (63):1-20.

KAYA, Z. (2002). Uzaktan Eğitim. Pegem A Yayıncılık Tic. Ltd. Şti., Ankara.

KIYMETLİ ŞEN, İ., HATUNOĞLU, Z., \& TERZİ, S. (2017). "Muhasebe Araştırmalarında Muhasebe Eğitiminin Yeri ve Önemi: Muhasebe Dergileri Üzerinde Bibliyometrik Bir Araştırma". Muhasebe Bilim Dünyası Dergisi, 19(1): 247-291.

KOÇ, B., \& YÜNCÜ, A. B. (2020). "Muhasebe Alanında 2004-2018 Yılları Arasında Hazırlanmış Lisansüstü Tezlerin İncelenmesi”. Muhasebe Enstitüsü Dergisi (62): 6375.

KUMAR, S., MARRONE, M., LIU, Q., \& PANDEY, N. (2020). "Twenty Years of the International Journal of Accounting Information Systems: A Bibliometric Analysis". International Journal of Accounting Information Systems, 39, 1-19.

MERIGÓ, J. M., \& YANG, J.-B. (2017). "Accounting Research: A Bibliometric Analysis". Australian Accounting Review, 27(1), 71-100.

NORTON, M. J. (2008). Introductory Concepts in Information Science. Information Today, Inc., Medford, New Jersey.

ÖZBEK, C. Y., \& BADEM, A. C. (2018). "Muhasebe ve Vergi Uygulamaları Dergisi'nde Yayımlanmış Makalelerin Bibliyometrik Analizi (2008-2017)”. Muhasebe ve Vergi Uygulamaları Dergisi, 11(2): 216-247.

T.C. Sağlık Bakanlı̆̆ COVID-19 Bilgilendirme Platformu, "Covid-19 Nedir?" "Pandemi", https://covid19.saglik.gov.tr/TR-66300/covid-19-nedir-.html,

https://covid19.saglik.gov.tr/TR-66494/pandemi.html, 30.07.2021. 
YEŞİL, T., \& AKYÜZ, F. (2018). "Muhasebe Alanındaki Ulusal Doktora Tezlerinin Bibliyometrik Analizi”. Muhasebe Bilim Dünyası Dergisi, 20(Özel Sayı): 440-472.

YÖK Dersleri Platformu, https://yokdersleri.yok.gov.tr/, 18.05.2021. 